\title{
US Multinationals and Human Rights: \\ A Theoretical and Empirical Assessment of Extractive vs. Non-Extractive Sectors
}

\author{
Indra De Soysa \\ Department of Sociology and Political Science, Norwegian University of Science and \\ Technology \\ Nicole Janz \\ School of Politics and International Relations, University of Nottingham \\ Krishna C. Vadlamannati \\ School of Politics and International Relations (SPIRe), University College Dublin (UCD)
}

\begin{abstract}
The consequences of foreign direct investment (FDI) for human rights protection are poorly understood. We propose that the impact of FDI varies across industries. In particular, extractive firms in the oil and mining industries go where the resources are located and are bound to such investment, which creates a status quo bias among them when it comes to supporting repressive rulers ("location-bound effect"). The same is not true for non-extractive MNCs in manufacturing or services, which can, in comparison, exit problematic countries more easily. We also propose that strong democratic institutions can alleviate negative impacts of extractive FDI on human rights ("democratic safeguard effect"). Using US FDI broken up into extractive and nonextractive industries in 157 host countries (1999-2015), we find support for these propositions. Extractive FDI is associated with more human rights abuse, but non-extractive FDI is associated with less abuse, after controlling for other factors, including concerns about endogeneity. We find also that the negative human rights impact of extractive FDI vanishes in countries where democratic institutions are stronger. Our results are robust to a range of alternative estimation techniques.
\end{abstract}

Keywords: human rights; foreign direct investment; multinational corporations; industry sectors; extractive FDI; democratic institutions

Notes: The replication files and other supplementary material are available upon request from the authors. 


\section{Introduction}

The literature on multinational corporations (MNCs) and their human rights impact has developed in different fields, most prominently in international law (Muchlinski, 2001; Ratner, 2001), but also in business ethics and Corporate Social Responsibility initiatives (Wettstein, 2009), development studies (Moran, 2006), political science (Kobrin, 2009; Hertel, 2019), and more recently, in international business (Wettstein et al., 2019). There is increasing agreement in the international community and across academic disciplines that firms bear certain human rights responsibilities, which has led to the adoption of the United Nations Global Principles for Business and Human Rights (Ruggie, 2011), the OECD Guidelines for Multinational Enterprises (OECD, 2011), and the creation of the United Nations Global Compact, to which stakeholders, including firms, subscribe for demonstrating commitment towards respecting human rights and higher social standards (see Rasche, Waddock \& McIntosh, 2013). Some see this as a positive development, where firms pay more attention to their societal impact (Vogel, 2005, 2010). Others bemoan the lack of initiatives in soft and hard law, especially in the extractive sectors, and argue that governments with control over natural resources and their MNC allies face little in the way of legal constraints (Schrempf-Stirling \& Wettstein, 2017). As Leif Wenar (2016) argues, the law that still applies in the global extractive industry, particularly regarding oil, is that "might makes right", or those that forcibly occupying natural resources become acceptable legal owners of them.

Alongside normative and legalistic discussions around the responsibilities of firms, and how these responsibilities might translate into policy, a range of studies has attempted to assess the effects of multinational corporations on human rights empirically, using either cross-country statistical analyses at the macro level, or single case studies on the micro level. There is, 
unfortunately, little interaction between empirical studies on the macro and micro level across disciplines, and existing evidence is highly mixed (Fontanier \& Kolk, 2007; Giuliani \& Macchi, 2014; Meyer, 2004). Importantly, studies have assessed the effects of all types of firms rather than examine more carefully the heterogeneity of reasons for why a firm might be complicit in human rights violations.

Most case studies, especially those examining controversial industries, or MNCs in areas of weak governance, find that human rights are not respected by firms (e.g., Eweje, 2005; Idemudia, 2009; Yu, 2008; Turcotte et al., 2007). On the other side of the spectrum, striving for generalization, the quantitative literature on foreign direct investment (FDI) has investigated cross-country patterns, and most of the statistical studies support the 'Washington Consensus' (Williamson, 1990, 2000), or liberal view, which is that MNCs have positive effects on government respect for human rights, with some confusion as to the direction of causality (Meyer, 1996; Cingranelli \& Richards, 1999; Apodaca, 2001; Apodaca, 2002; Hafner-Burton, 2005).1

The recent business literature has criticised quantitative studies for lumping all forms of FDI together and for ignoring the fact that industry-level characteristics are likely to influence firms' human rights impact (Fortanier \& Kolk, 2007; Giuliani \& Macchi, 2014). Industries differ along economic and social dimensions, such as production inputs and outputs, technologies, choice of location, and the "footlooseness" of firms (Godfrey, Hatch \& Hansen, 2010). Since FDI has become increasingly diverse over the last decades, its global impact may not be easily determined by using aggregate FDI data. Moreover, it is not clear at all how and in what ways

1 Hardly any statistical studies find negative effects of FDI on rights (Clark \& Kwon, 2018; Smith, Bolyard \& Ippolito, 1999). Many quantitative studies find that there is no significant link, possibly because positive and negative effects from different industry sectors cancel each other out when aggregate FDI is used (e.g. Sorens \& Ruger, 2012; Cao, Greenhill \& Prakash, 2012). 
firms might be directly responsible for violating the rights of people, and what portion of the blame might be assigned to the economic motives of companies relative to the political motives of host governments.

We revisit the question of FDI's impact on human rights by integrating insights from qualitative work, namely that industry sectors and host country context matter. We build on two quantitative pioneering studies that are more refined than previous work. Janz (2018) finds that the presence of multinational corporations in developing countries is positively connected to rights outcomes, but only when FDI is invested in industries with medium or high skills and technology levels, such as services. Blanton and Blanton (2009) show that the ability of countries to attract FDI via lax regulation, or suppressed labour standards, only works for some industry sectors and not for all types of FDI. These studies provide preliminary evidence that effects from FDI might vary across industries, but we do not yet know the specific reasons why some FDI has negative impacts, or how host-country conditions influence the locational environments that firms choose. Given the risks attached to political instability, and the general aversion of companies to violence-based risks, why firms would decide to locate in high risk environments must lie in locational advantages.

We ask, therefore, what is the impact of FDI on human rights across different industry sectors, and what differences exist if any between extractive (oil, mining) vs. non-extractive industries (manufacturing, services)? We focus on this distinction because among qualitative case studies, there is a great deal of attention paid to the negative impacts in extractive sectors, which has amounted to the theory of the so called "resource curse" that drives autocratic and corrupt politics in resource-wealthy states (e.g. Eweje, 2006a, 2006b, 2009; Idemudia, 2009; MacDonald \& McLaughlin, 2003; Ross, 2012). Many local communities and social activists are 
willing to give up on potential economic benefits from FDI and oppose new extractive investment, because they fear that extraction leads to human rights abuses in local communities, where foreign companies run rough shod over the interests and demands of people (Dashwood, 2014; Mutti, Yakovleva, Vazquez-Brust, \& Di Marco, 2012).

Our argument is twofold: First, extractive FDI is location-bound, so that firms have little incentive to punish repressive host countries given that they are the "legal" owners of these assets. Even if there are external incentives for firms to divest from repressive regimes due to voluntary industry standards and pressure from NGOs and the media, extractive firms are unlikely to lobby host country governments for better human rights conditions or threaten with withdrawal because they can be easily replaced. Indeed, extractive MNCs are bound by the lowmobility features of their sector, and threats to leave would simply not be credible ("locationbound effect"). Moreover, when a company is specialized in extraction, recovering losses from the sunk costs will depend heavily on retaining access to the natural resources.

Second, we argue that foreign investors operate not only within industries, but they are also subject to domestic country context. If firms decide to invest in - or remain in - repressive host countries, they may become complicit in wrongdoings since they provide revenue to such governments (Clapham, 2006; Wettstein, 2010). This negative view is particularly relevant for institutionally weak countries. In other words, host country potential for handling dissent generated by an FDI project is dependent on strong institutional quality.2 Even though the challenge of domestic governance gaps and institutional voids is a core concern in the Business and Human Rights field (Wettstein et al., 2019), there are hardly any quantitative studies on FDI and human rights that test for such conditional effects, with rare exceptions (Wang, 2017; Clark and Kwon, 2018). The studies that do exist do not distinguish between different industries. We 2 We thank an anonymous reviewer for pointing us in this direction. 
propose that democratic institutions provide safeguards for human rights protection by keeping leaders (and MNCs) in check ("democratic safeguard effect"). The effectiveness of global voluntary codes of conduct, such as the 2011 UN Guiding Principles on Business and Human Rights (Ruggie, 2011), or the updated OECD Guidelines for Multinational Corporations (OECD, 2011), are likely to be influenced by the interplay between industry sector characteristics and host country institutions. We shed more light on this by examining this issue empirically.

We examine US FDI located within 157 host countries (1999-2015), for which disaggregated data are available. We find that extractive FDI is associated with negative effects on human rights, but non-extractive FDI shows positive effects, after controlling for a range of relevant factors, including the possibility of endogeneity. We further examine the conditioning effect of host country institutions, finding that the negative effect of extractive FDI on human rights becomes insignificant in countries where institutions are stronger. The results are robust to sample size, estimation technique, and alternative specifications. The rest of the paper is organized as follows: In the next section, we discuss the features of different types of FDI, in particular, extractive investment, and how they are linked to human rights within the wider country context. We then test the proposed links empirically in a cross-country time-series analysis. The conclusion outlines the implications of our findings for future research.

\section{Extractive FDI, human rights, and democratic safeguards}

Our overall argument rests on the assumption that firms which operate in the same sector will adjust their behaviour in a similar way, which leads to institutional isomorphism and homogenisation (DiMaggio and Powell, 1983; Chand \& Fraser, 2006; Griffin and Mahon, 1997). Each industry, such as natural resource extraction, manufacturing, or services, has a normative, 
regulative and economic structure to which MNCs adapt their behaviour (March \& Olsen, 2006; Scott, 1995). For example, industries differ in their use of skill levels, location decisions, the competitive behavior among firms, or role of branding, and CSR efforts (Beschorner \& Hajduk, 2017; Giuliani \& Macchi, 2014; Godfrey et al., 2010; Meyer, 2004). While there is also withinindustry variation of companies' individual behavior, we propose that it is the unique features of industry sectors that shape overall patterns of human rights impact on host countries because most firms, by and large, face the same incentives shaping their behavior.

The focus of our theory lies in distinguishing between extractive versus non-extractive FDI, because extractive sectors, such as oil or mining, have two distinct industry-related features that are different from other sectors. First, under the 'natural resource-seeking motive', foreign investment in extractive sectors requires developing and controlling the sources of supply of raw materials, which are the primary commodities required for production. Second, extractive FDI involves huge capital investments. Therefore, investment of extractive FDI may not be able or willing to avoid investing in repressive regimes where resources are located; and divestment from host countries during times of political instability and repression is almost impossible because of high sunk costs and the location-bound nature of this type of FDI (Vernon, 1971). Moreover, global law recognizes even highly repressive regimes in control of natural resources as the legal owners of these assets according to the principle of "might makes right" (Wenar, 2016). Investments in extractive sectors are also more vulnerable to issues of domestic security, because a change in the status quo might mean replacement of leaders, negotiating a new deal, and perhaps complete or partial loss of monopoly rents. A similar logic has been used to explain why ruling elites in resource wealthy countries avoid reforms - the fear of replacement and the loss of future monopoly rents (Acemoglu \& Robinson, 2008). Extractive investments may, in 
other words, have a status quo bias because of insecurity of rights obtained for extracting natural resources. High sunk costs, thus, reduce the incentives of extractive FDI to sanction ruling elites who promise stability by using repression to weaken opposition movements or local unrest. Simultaneously, governments facing dissent know these constraints, and can safely ignore extractive MNC preferences of not wanting to be associated with repression. Crucially, due to high sunk costs and the location-bound nature of extractive FDI, threats of withdrawal will not be credible, so that MNCs in the extractive sector have little leverage over repressive host countries.

This location-bound, high-sunk cost nature of extractive industries perpetuates wellknown issues including human rights challenges. For example, the location of resources often involves forced displacement and a loss of livelihood for local communities, exploitation of lowskilled workers, and environmental pollution (Eweje, 2006a, 2006b). These issues have led to protests, sabotage and subsequent security challenges across extractive sectors in the past (Dashwood, 2014; Mutti et al., 2012). A prominent example is the Niger Delta, where government security forces used violence against activists and local protesters (Frynas, 1998; Idemudia, 2009; MacDonald \& McLaughlin, 2003). Indeed, a detailed list of cases on human rights violations registered under The Alien Tort Claims Act (ATCA) of 1789 of the US government against US firms operating in various developing countries reports that the majority of the cases are associated with extractive investments (see our summary in the appendix).

Our argument does not claim that there is no within-industry variation in the extractive sector, or that all extractive firms are bound to actively violate human rights. Firms do have agency in how they behave towards their employees, local communities, and the environment, and they are increasingly being held accountable via industry-level standards, multilateral 
treaties, and international law. For example, the 2013 OECD Due Diligence Guidance for Responsible Supply Chains of Minerals from Conflict-Affected and High-Risk Areas (OECD, 2013), and the 2017 OECD Due Diligence Guidance for Meaningful Stakeholder Engagement in the Extractive Sector (OECD, 2017), aim to support firms in reducing their negative impacts. The 2010 Conflict Minerals provision of the Dodd-Frank Act for US companies, which now have to disclose the use of conflict minerals in their supply chains, has similar goals. Similarly, a crucial finding from the 'naming and shaming' literature is that recent developments to hold firms accountable have created pressure on foreign investors to divest from repressive regimes to avoid reputational damage (Barry, Clay, \& Finn, 2013; Vadlamannati, Janz, \& Berentsen, 2018). This issue is also discussed within the business literature, where firms might be seen as political and powerful actors that can step in when states are unable to provide public goods to their citizens, lobby governments for improvements, and drive a "race to the top" (Matten \& Crane, 2005; Scherer \& Palazzo, 2011; Westermann-Behaylo, Rehbein, \& Fort, 2015).

However, there are features of the extractive industry that are unique among other FDI high sunk cost and location-bound raw materials - which are likely to strongly influence the behavior of firms in problematic host environments. Even if some 'good' extractive firms wanted to pressure repressive regimes to improve the rule of law and human rights protection, any exit threat in the extractive industry is not likely to be credible, as host governments are also aware of the low mobility of such investment. In sum, a combination of 'bad behavior' of some - but surely not all - extractive MNCs, together with low mobility of such FDI and low credible exit threats, we expect this kind of FDI to have negative impacts on human rights protection. The examination of this argument is crucial because most recent developments in hard and mostly soft law to improve MNCs' behavior, as well as pressure from NGOs and the media, may only 
be effective to some extent - they may not change the industry's effect as a whole due to the nature of how raw material extraction works.

In comparison, non-extractive FDI, for example, service sectors or manufacturing, is more footloose relative to extractive FDI, and has fewer barriers against its choice of location (Kobrin, 2009). MNCs can divide up their activities in many locations and use outsourcing from multiple plants in their overall risk-reducing strategies (Blonigen, Davies, Waddell, \& Naughton, 2007) to hedge against risk emanating from one specific location. The sunk cost involved in nonextractive sectors can, at times, also be high; but non-extractive sectors are not generally bound to particular raw material locations, where the real value is in the ground. Non-extractive industries which have heavily invested in a host country may not have any interest to leave repressive regimes, but if they wanted to, they could. Any exit threat would be much more credible than in the extractive industry. Moreover, manufacturing and service FDI are likely to be more important where the 'resource curse' effects of high dissent and bad governance are generally absent, simply because non-extractive FDI is deterred by political instability and corruption, which are often associated with the resource curse (Asiedu, 2006; Globerman and Shapiro, 2003). This means that not only is a good environment, such as democracy and good governance, attractive to non-extractive FDI, but this FDI is less biased towards the status quo and less location-bound, thereby having greater freedom to disassociate from human rights violations and threaten exit. This does not mean, however, that other kinds of FDI are absent where natural resources exist, but that the policy environments in resource dependent states, often characterized by high corruption and predatory regimes, are likely to attract less nonextractive FDI (Globerman and Shapiro, 2003; Wenar, 2016). 
To sum up, extractive multinationals have to go where the resources are located, which creates a status quo bias among them when it comes to supporting repressive rulers. Under these conditions, FDI is likely to be far more aligned with state actions despite damage to reputations. The same is not true for non-extractive MNCs, which can exit more easily, or threaten credibly to do so. Thus, we propose to test the following main hypothesis:

\section{Hypothesis 1:}

"Location-bound effect": Ceteris paribus, extractive FDI is connected to worse government respect for human rights, in comparison with non-extractive sectors.

We argue further that this relationship can be expected to vary according to host country institutions. UN Special Representative for Business and Human Rights (SRSG) John Ruggie has stated that the "root cause of the business and human rights predicament today lies in the governance gaps created by globalization - between the scope and impact of economic forces and actors, and the capacity of societies to manage their adverse consequences.” (Ruggie, 2008: 189). Not all countries that receive extractive FDI are repressive regimes (e.g. Canada, Norway, Australia), and their positive human rights record indicates that democratic institutions can significantly mitigate negative impacts. One of the most accepted theories in comparative human rights research is that democratic institutions increase the costs of using repressive behavior for leaders, because they can be voted out of office. They also provide alternative mechanisms of control for citizens via participation, so that grievances are expressed at the ballot rather than in violent protests (Davenport, 2007). Domestic institutions of host countries that reduce instability can benefit from FDI. Democratic institutions can also mitigate the negative effects from FDI 
once it is present, keeping leaders' repressive tendencies in check, and shaping adequate policy responses that steer away from repressive action e.g. during security crises around extraction sites (Wang, 2017). In fact, protests and instability may not even occur in the first place, because democratic institutions provide for other ways for citizens to voice disagreement with MNC's, including the resort to legal action (Schrempf-Stirling \& Wettstein, 2017). Clark and Kwon (2018) examine if the effect of FDI stock varies by regime type, showing that the harmful impact of foreign capital on human rights might be significantly weaker in democratic states. We extend this argument to extractive industries and propose that democratic institutions condition the effects of extractive FDI in a way that reduce human rights repression.

\section{Hypothesis 2:}

"Democratic safeguard effect": The effect of extractive FDI on human rights is conditional on democratic institutions, which reduce negative impacts from FDI.

\section{Data \& Methods}

\subsection{Model Specifications}

To examine our theoretical propositions, we apply panel data covering 157 countries (see Appendix 2 for list of countries) over the 1999-2015 (17 years) period for which we have US FDI data. Since some of the data are not available for all countries for all years, our dataset is unbalanced. We estimate:

$$
\operatorname{PTS}_{i t}=\alpha_{i}+\beta H_{i t-1}+\beta Z_{i t-1}+\gamma_{i}+\delta_{t}+\omega_{i t}
$$


Wherein, $P T S_{i t}$ is our outcome variable, which measures the degree to which a government practices the violations of physical integrity rights of citizens measured by the Political Terror Scale (PTS) index, ${ }^{\boldsymbol{\alpha}_{i}}$ is the intercept, $\boldsymbol{H}_{\boldsymbol{i t - 1} \boldsymbol{I}}$ is our main variables of interest, $\boldsymbol{Z}_{\boldsymbol{i t - 1} \boldsymbol{I}}$ are control variables, and $\gamma_{i}$ is country dummies, $\delta$ is year-specific dummies, and $\omega_{\text {it }}$ is the error term.

The PTS index measures the amount violations of personal integrity rights, such as politically motivated execution, torture, forced disappearance, unlawful imprisonment and discrimination based on political and religious beliefs (Gibney \& Dalton, 1996). The PTS data are generated from two sources of information-namely, from Amnesty International country reports and annual country reports supplied by the United States State Department. The PTS scale is widely used and shows high correspondence with other measures of state repression. The PTS is defined as follows.

1 if countries are under secure rule of law, political imprisonment and torture are rare, and the political murders are extremely rare;

2 if imprisonment for non-violent political activities is limited, torture and beating are exceptional, and political murder rare;

3 if political imprisonment is extensive, execution and political murder may be common, and detention for political views are acceptable;

4 if the practices of level 3 are expanded to a larger segment of population, murders and disappearances are common, but terror affects primarily those who interest themselves in political practices and ideas

5 if level of terror are population wide, and decision makers do not limit themselves by which they pursue private and ideological goals

Therefore, a higher value denotes more violations of human rights. We take the average of the two measures from the Amnesty International and the US State Department to avoid any subjective biases, especially in the data from the State Department as suggested by Qian and 
Yanagizawa (2009) and Poe et al. (2001).3 This index is a commonly accepted measure for human rights protection and has been used widely in the literature (Vadlamannati et al., 2018; Davenport \& Nordas, 2013; Davenport \& Armstrong, 2004; Walker \& Poe, 2002). The mean of the PTS index during 1999-2015 is 2.68 with a standard deviation of 1.09 .

$\boldsymbol{H}_{\text {it-1 } \mathbf{1}}$ captures our main variables of interest, which are lagged by one year to reduce bias from simultaneity. These include (i) total US FDI stock per capita (log), and (ii) disaggregated US FDI per capita (log) provided by the US Bureau of Economic Analysis (BEA) database on Balance of Payments and Direct Investment Position.4 The BEA defines US direct investment abroad as either ownership or control of 10 percent or more of a foreign business enterprise, voting securities or the equivalent.5 The data is recorded in historical cost basis and hence cannot be identifiable in constant nor current prices (Blanton \& Blanton, 2009). The BEA data captures the US FDI position abroad disaggregated by industry sector from 1989 onwards. It should be noted that the industry classification of US FDI by the BEA was converted from Industrial Classification (SIC) to North American Industry Classification System (NAICS) in 1998. Therefore, we use the data from 1999 onwards for consistency. As mentioned above, we use FDI per capita and log the data to address the problem of skewness. We collect the data on extractive (oil, petroleum, mining and minerals) and non-extractive (manufacturing and services) US FDI for 157 developing countries based on the availability of data at the BEA. We expect that it is mainly the penetration of extractive investments vis-à-vis non-extractive investments that are

3 PTS Amnesty score + PTS State Department, divided by two. For a detailed description on methodology, see: http://www.politicalterrorscale.org/Data/ (accessed Dec 1, 2017).

4 Although the industrial classification of US FDI by the BEA in 1998 was converted from Industrial Classification (SIC) to North American Industry Classification System (NAICS), this does not greatly affect us as we are more interested in FDI in extractive sectors like petroleum, gas and mining combined together relative to other sectors. See https://www.bea.gov (retrieved October 25, 2019).

5 Direct investment abroad is defined by the US Bureau of Economic Analysis (BEA) as "ownership or control, directly or indirectly, by one U.S. person, or entity, of 10 percent or more of the voting securities of an incorporated foreign business enterprise or an equivalent interest in an unincorporated foreign business enterprise." (see https://www.bea.gov/help/glossary (retrieved October 25, 2019). 
associated with more human rights violations in host countries. Since most countries have some of both types of investments, we estimate their independent effects on human rights.

The vector of control variables $\left(\mathbf{Z}_{\mathbf{i t}}\right)$ includes other potential determinants of human rights which we obtain from the extant literature on the subject. We follow the pioneer studies of Poe and Tate (1994) and Poe et al. (1999) and other comprehensive evaluations on determinants of repression (Carey \& Poe, 2004; Landman, 2006). We avoid the trap of "garbage-can models" or "overfitting" by keeping our models simple (Achen, 2005; Schrodt, 2014). We adopt the conservative strategy of accounting only for key factors that may directly associate with our main independent variables, exploring several other variables in robustness checks. Accordingly, we control for economic development by including per capita income (log) in US\$ constant prices taken from the World Development Indicators 2018 (WDI). Country size (population, log) is an important control because governance and rights protection is more challenging in larger countries, which may also attract higher values of FDI due to market size. Next, we include a measure of regime type based on the Polity IV data (Gurr \& Jaggers, 1995). We create a set of dummies for democracy and autocracy using the Polity IV index above +6 representing full democracy, which takes the value 1, and 0 otherwise.6 Likewise, we include an autocracy dummy, which takes the value 1 if the Polity IV index is below -6 , and 0 if not. The reference category is made up of imperfectly-institutionalized regimes, referred to as anocracies (Fearon \& Laitin, 2003). Additionally, we include a variable measuring civil war that takes the value 1 if there is armed conflict between an organized rebel group and a state where at least 25 deaths have occurred in a single year, and 0 otherwise (Gleditsch et al., 2002). Naturally, an ongoing civil war is likely to affect the degree of state repression. We also include a count of the number of years of civil peace to distinguish between immediate post-war situations and the history of 6 Note that estimating the models with the original Polity IV index does not alter our results substantially. 
peaceful conditions since these factors affect our independent variables (Beck, Katz \& Tucker, 1998).

In addition, we include oil export dependency, which is related to repression due to the so called 'resource curse' (de Soysa \& Binningsbø, 2009). Following Michael Ross, we construct an oil production dummy taking the value 1 if oil and gas production exceed $\$ 100$ per capita, and 0 if not (Ross, 2012). It is noteworthy that we lag all controls by one year to avoid simultaneity bias. Finally, we also include a lagged dependent variable (LDV) in our models. There are two reasons for its inclusion. First, a lagged dependent variable also captures regional diffusion and spill-over effects that are not directly observed (Neumayer, 2005). Second, it is theoretically plausible that bureaucratic decisions associated with the organs of state repression use past decisions to repress or not in present circumstances, so that this behavior can be quite sticky (Poe, Tate, \& Keith, 1999). The descriptive statistics are presented in Appendix 3. For more details on data definitions and sources, see Appendix 4.

The baseline models are estimated using the Generalized Least Squares Fixed effects (FGLS) estimator. The pooled data are susceptible to having highly correlated data between and across panels that could lead to optimistic standard errors (Beck and Katz, 1995). Using FGLS over a simple OLS allows estimations in the presence of AR (1) autocorrelation within panels and cross-sectional heteroscedasticity across the panels. As mentioned, we control for country and year-specific fixed effects. We also use Ordered Logit models since the outcome variable is rank ordered (1-5). In ordered logit estimations, we include only year-specific dummies because of including two-way fixed effects in non-linear estimations may be problematic due to the wellknown ‘incidental parameter problem’ (Lancaster, 2000, Wooldridge, 2002). 


\subsection{Endogeneity concerns}

It is quite possible that our key explanatory variables - US FDI and its disaggregated measures are endogenous to having fewer human rights violations. That is, it might be that governments committed to respecting human rights attract more FDI as suggested by Blanton and Blanton (2006, 2009). For example, the expectation of instability arising out of dissent and uprising could deter foreign investors. Not taking this endogeneity into account would induce bias in our estimate of the effect of FDI on human rights. We thus control for endogeneity concerns by replicating the baseline estimations by using the system-GMM estimator as suggested by Arellano and Bond (1991), Arellano and Bover (1995) and Blundell and Bond (1998), which is considered most appropriate in the presence of endogenous regressors. The dynamic panel GMM estimator exploits an assumption about the initial conditions to obtain moment conditions that remain informative even for persistent data. Second, and the most important reason why we use the GMM estimator, is because of the Nickell bias problem, as FGLS estimations tends to be inconsistent to the inclusion of a lagged dependent variable and the presence of two-way fixed effects simultaneously in a short panel like ours (Nickell, 1981).

The GMM results are based on a two-step estimator implemented by Roodman (2006). We apply the Sargan-Hansen test on the validity of the instruments used (amounting to a test for the exogeneity of the covariates) and the Arellano-Bond test of second order autocorrelation, which must be absent from the data in order for the estimator to be consistent. We treat both lagged dependent variable and our hypotheses variables (namely, total US FDI, extractive and non-extractive FDI) as endogenous, and the other variables as strictly exogenous. As before, we include time dummies in the GMM regressions. In order to minimize the number of instruments in the regressions, we collapse the matrix of instruments as suggested by Roodman (2006). 


\subsection{Interaction effects}

Next, we examine whether the negative effects of FDI on human rights are more prevalent in countries with weak institutions. This is an important consideration because extractive activities by firms are also prevalent in institutionally strong countries like Australia, Canada, Norway, among others where pressures for maintaining status-quo may not mean that human rights are violated. To test this proposition, we introduce an interaction term:

$$
P T S_{i t}=\alpha_{i}+\beta(H \times i v)_{i t-1}+\beta H_{i t-1}+\beta i v_{i t-1}+\beta Z_{i t-1}+\gamma_{i}+\delta_{t}+\omega_{i t}
$$

Wherein, $\boldsymbol{\beta}(\boldsymbol{H} \times \boldsymbol{i v})_{i t-\mathbf{1}}$ is the interaction term between extractive FDI per capita $(\log )$ and the conditioning variable measuring the "quality of institutions" in a host country namely, the Polity regime type index $\left(\boldsymbol{\beta} \boldsymbol{i} v_{i t-1}\right)$ in country $\boldsymbol{i}$ during year $\boldsymbol{t}-1$. The interaction term is lagged by oneyear. We use Polity II index which is coded on a -10 to +10 scale, where the directionality of the index runs from strict autocracy to full democracy. The index is derived from coding of the following key components, which capture the strength of institutions in a polity; namely, competitiveness and openness of executive recruitment, constraints on the power of chief executive and competitiveness of political participation. These interaction effects will allow us to understand whether the negative effects of extractive FDI are concentrated in countries with weak institutions. Once again, we use the FGLS two-way fixed-effects estimator and generate marginal plots to assess the substantive effects of the conditional results. 


\section{Empirical Results}

Tables 1-4 present our regression results. Table 1 displays the results estimated using FGLS twoway fixed effects models, which examine the relationship between human rights abuse and US FDI by sector, controlling for other determinants which are added in a stepwise manner. Table 2 presents the replication of the baseline models using ordered logit estimators, and we report the marginal effects from ordered logit estimations in Figure 1. Table 3 presents the results addressing endogeneity concerns on the effects of US FDI and disaggregated measures on human rights violations using the SGMM method. Finally, Table 4 reports the results for extractive FDI in interaction with our institutional measure, and we present the conditional plot for this result in Figure 2.

**********TABLE 1 ABOUT HERE**********

As seen from column 1 in Table 1, the impact of total US FDI per capita on human rights violations is statistically insignificant. When other controls are added in the model, total US FDI has a statistically significant negative coefficient, independently of all the controls. Since higher values of the PTS index indicate more rights violations, the negative coefficient for total US FDI suggests that more FDI is related to better rights protection, similar to other studies on FDI and human rights (Meyer, 1996; Cingranelli \& Richards, 1999; Apodaca, 2001; Apodaca, 2002; Hafner-Burton, 2005). As seen in column 2 in Table 1, at the mean value of US FDI per capita $(\log )(1.12)$ there is a 0.06-point decline in the PTS index, independent of other control variables. A standard deviation increase in FDI per capita $(\log )(1.56)$ above the mean value lowers the PTS index by roughly 0.17 points, which is significantly different from zero at the $1 \%$ level. In 
column 3, we replace total US FDI with two disaggregated measures namely, extractive and nonextractive FDI per capita $(\log )$. We find that extractive FDI has a positive impact on PTS index, net of all the controls including non-extractive FDI, which is statistically significant at the $1 \%$ level. The positive effect suggests that an increase in extractive investments increases the level of human rights violations. In the same model, we find contrary results related to non-extractive FDI, which is also significantly different from zero at the 5\% level. The substantive effects suggest that a standard deviation increase in extractive FDI per capita (log) is associated with an increase in PTS index by 0.1 points. However, one standard deviation increase in non-extractive FDI per capita (log) is associated with a decrease in PTS index by 0.23 points, which is double the effect of extractive FDI. Thus, even when extractive FDI is accounted for, the level of nonextractive FDI has a strong positive effect on human rights protection. These effects of nonextractive FDI and extractive FDI, when included together in the same model, remain significantly different from zero at the $5 \%$ and $1 \%$ levels respectively as shown in column 4 . The substantive effects of non-extractive FDI continue to be higher than that those of extractive FDI, net of all the control variables. Finally, our results on extractive vis-à-vis non-extractive FDI on human rights are robust to the inclusion of a lagged dependent variable in column 5 of Table 1. Thus, even when estimating the within-country variance with a lagged dependent variable, the hypothesis that extractive FDI reduces and non-extractive FDI increases human rights protection is upheld. Overall, these results support the argument for a negative "location-bound effect" (hypothesis 1) associated with extractive investment. These results support studies focused on mining projects that show that company-community conflicts increase where mining projects locate (Berger et al., 2017). 
The results on the control variables are consistent with those reported by other studies. The level of income largely remains statistically insignificant. We find that countries with a larger population have more violations of rights. However, this effect is not consistent across all the models. We suspect that both income and population change slowly over time and hence are correlated with the fixed effects. This could be the reason why both variables are highly significant at the $1 \%$ level in ordered logit estimations in Table 2 where country fixed effects are not controlled. As expected, in all the models irrespective of estimation technique (in Table 1 and 2), democracy is associated with fewer human rights violations. Likewise, civil peace years are associated with lower incidences of human rights abuse and civil conflicts with higher violations of human rights, as others also report (Poe \& Tate, 1994, Poe et al., 1999). The variable for oil exporters in general is largely insignificant when estimating the models with the linear estimator in Table 1. Interestingly, our main results on extractive and non-extractive FDIs remain highly significant despite the inclusion of several statistically significant controls.

Next, due to the rank-ordered nature the dependent variable PTS, we re-estimate the models using ordered logit controlling for year-specific dummies. These results are reported in Table 2 .

**********TABLE 2 ABOUT HERE**********

As before, total US FDI per capita (log) is negative and significantly different from zero at the $1 \%$ level in both column 1 and in column 2 where other controls are included. Likewise, we also find in column 3 and 4 that extractive FDI increases human rights violations while non-extractive FDI decreases violations. These results are largely similar to those reported in our baseline 
estimations in Table 1. Our results of US FDI's impact on human rights, thus, remain robust to utilizing alternative estimation techniques.

\section{***********FIGURE $1 \mathrm{ABOUT} \mathrm{HERE}^{* * * * * * * * * * *}$}

To understand the magnitude of our results in the ordered logit models, we compute the marginal effects at the mean of both extractive and non-extractive FDI per capita (log). It is noteworthy that marginal effects in ordered logit are not straightforward to interpret. We follow Dreher et al. (2010) and compute estimated probabilities before and after a shock of one standard deviation of extractive and non-extractive FDIs on the PTS (see Figure 1). Accordingly, nonextractive FDI has a higher impact compared to extractive FDI. The estimated probability of observing the PTS index values of 1, 2 and 3 (at the mean of all variables) are 4\%, 25\% and $19 \%$, respectively, while index values 4 and 5 occur with a predicted probability of $3 \%$ and 0.3\%. However, after an increase in non-extractive FDI per capita (log) by one standard deviation these predictions get higher, i.e., 6\% and 29\% for low PTS index values 1 and 2 (fewer or no human rights violations). They decrease for the higher PTS index values 3, 4 and 5 to $13.5 \%, 1 \%$ and $0.1 \%$, respectively. Similarly, after an increase in extractive FDI by one standard deviation the predictions get marginally lower for low PTS index values, i.e., $3 \%$ and $23 \%$ for 1 and 2, while they increase for the high PTS index values 3, 4 and 5 to $20 \%, 3 \%$ and $0.4 \%$, respectively. These effects are not only statistically significant, but also quantitatively important.

Next, we examine our models controlling for possible endogeneity between human rights and types of FDI. As discussed earlier, we make use of the System-GMM method. 
Table 3 presents the results of the models estimated using GMM. The Hansen test and the Arellano-Bond test do not reject the SGMM specifications at conventional levels of significance across the columns, indicating that endogeneity may not be a major problem. The Hansen $J$ Statistic clearly shows that the null-hypothesis of exogeneity cannot be rejected at the conventional level of statistical significance. As can be seen from column 1, total US FDI per capita $(\log )$ is negative and significantly different zero at the $1 \%$ level. These results remain robust to the inclusion of various control variables in column 2 . In column 3 and 4, we include both extractive and non-extractive measures of US FDI per capita (log). As seen, extractive FDI is positive and significantly different from zero at the $1 \%$ level in column 3 and 4 . Notice that even after controlling for potential feedback from the PTS index, the coefficient value of column 5 in Table 1 (in which a lagged dependent variable is also included) is reduced only marginally. Likewise, we find that non-extractive FDI per capita (log) has a significant negative impact on the PTS index at the $1 \%$ confidence level. These results highlight an interesting point. First, they show that the size of the coefficient for both forms of FDI are, by and large, similar in GMM and non-GMM regression estimates, and they suggest that endogeneity may not be a major problem.

\subsection{Conditional Effects}

Thus far, we examined the direct effect of FDI on human rights violations. Next, in Table 4, we examine whether the effects of extractive FDI, in particular, are conditional on the level of institutional quality. We introduce an interaction term between extractive FDI and the Polity index, which is our measure of institutional quality in Table 4. 
In column 1, only the interaction term is included without any control variables. We do however control for non-extractive FDI. While in column 2, we include all other control variables, column 3 also includes a lagged dependent variable. As seen in column 1-3, the interaction term is negative but statistically insignificant. Interestingly though, our extractive FDI per capita (log) measure on its own, i.e., when the institutions measure is 0 , has a positive and statistically significant effect on human rights violations. Likewise, the effect of institutions (Polity index) on human rights violations is negative when extractive FDI per capita is 0 , which is statistically significant at the $1 \%$ level. It is important to note that the interpretation of the interaction term even in linear models is not straightforward. Consequently, a simple t-test on the coefficient of the interaction term is not sufficient to examine whether the interaction term is statistically significant, or otherwise (Ai \& Norton, 2003).

We rely on marginal plots for assessing the nature of the conditional effects. The interactive effect is best assessed with a margins plot which depicts the magnitude of the interaction in Figure 2. To calculate the marginal effect of extractive US FDI per capita (log) on the PTS index, we take into account both the conditioning variable (Polity index) and the interaction term, and we display graphically the total marginal effect conditional on the Polity index. The y-axis of Figure 2 displays the marginal effect of US extractive FDI per capita $(\log )$, and the marginal effect is evaluated on the Polity index variable on the $\mathrm{x}$-axis. Note that we include the 95\% confidence interval in Figure 2. 
In line with our theoretical expectations, extractive FDI per capita (log) increases the PTS index (at the $95 \%$ confidence level at least) when the Polity index is lower than the score of 6 . In other words, the marginal effects are significant and positive when the upper bound of the confidence interval is above zero. The marginal effects suggest that extractive FDI increases the PTS index by 0.1 points when the Polity index score is 6 . Consider a country which has a Polity index score of -10 (a strict autocracy). A point increase in US extractive FDI per capita (log) in a country with a Polity score of -10 would increase the PTS index by almost 0.15 points, i.e. FDI is connected with more human rights abuse at high levels of autocracy. Interestingly, the margins plot also shows that the effect of extractive FDI on human rights violations becomes statistically insignificant once the Polity IV index of a host country is above 6, i.e., in a country with stronger democratic institutions. These results suggest that the negative effects of extractive FDI on human rights are more prevalent in host countries with weak institutions, supporting our hypothesis 2, which proposed a "democratic safeguard effect". This might also be one of the main reasons why FDI in extractive industries in countries, such as Australia, Canada, Norway, and Chile, is not associated with the repression of human rights.

\subsection{Checks on Robustness}

We examine the robustness of our main findings in the following ways. First, we exclude highincome OECD countries, which seldom have bad human rights records. It is quite plausible that the results might be driven by these countries. The new results (without high-income OECD 
countries, reported in Table A in our supplementary file)7 remain robust and mirror those reported in our baseline estimations.

Second, we use the PTS in its disaggregated version, which is based on only Amnesty International reports, to avoid any form of biases which are likely to be present in the PTS index based on sources by the US State Department (Qian \& Yanagizawa, 2009). Our new results with the Amnesty International PTS index (reported in Table B, supplementary file) still show strong significant effects for extractive FDI and the abuse of human rights. These results remain robust to the inclusion of a lagged dependent variable and alternative estimations techniques, such as ordered logit.

Third, following de Soysa and Vadlamannati $(2012,2011)$ we run all our results using an alternative measure for human rights, the physical integrity rights index (PIR hereafter), sourced from the Cingranelli and Richards Human Rights Database (Cingranelli \& Richards, 1999). This measure is available annually from 1981 onwards until 2011 for 195 countries.8 The source of information used for coding the index are the same as for the PTS, but the PIR data are collated somewhat differently.9 The PIR is an additive index constructed from measures of torture, extrajudicial killing, political imprisonment, and disappearances. It ranges from 0 , meaning no government respect for these four human rights to 8 , or full government respect for these four human rights. Once again, our results (in Table C of our supplementary file) based on PIR index as dependent variable remain robust.

Fourth, we estimate our baseline models by excluding outliers in all our FDI variables, as extreme values could influence our main findings. Excluding the outliers aggregated and

\footnotetext{
7 The supplementary file will be available in our replication materials upon request.

${ }_{8}$ One main reason why we do not use this measure in our main analysis is the data is available only until 2011.

9 For more on construction of the dataset and coding rules, see CIRI Human Rights Data project, retrieved February 27, 2019, from: http://www.humanrightsdata.com.
} 
disaggregated for US FDI per capita from the sample does not change our main results substantially (Table D). Fifth, we use an alternative method of operationalization of our main variable of interest. Instead of per capita FDI, we use FDI measures as a share of GDP, which is an alternative proxy of penetration of FDI into the host economy, and FDI measured in US\$ million (log). Our baseline specifications estimated using these alternative FDI measures remain robust and, in the direction, reported above (Table E).

Sixth, Clarke and Kwon (2018) propose that any negative effects of FDI on human rights might be diminishing over time, mostly because there is now less primary sector FDI within overall FDI, which may have driven the negative effects of FDI. We extend this argument by proposing that even for problematic extractive FDI, improvements over time are plausible because new guidelines and voluntary codes for the extractive industries aim at changing foreign investors' impact on the ground.10 We test this proposition by interacting both measures of FDI, extractive and non-extractive FDI per capita (log), with year-specific dummies. We report these results in Table $\mathrm{F}$ in the supplementary file, and in Figure A here. We find that the negative human rights effects of extractive FDI tend to increase over time, rather than diminish. The positive effects of non-extractive FDI on human rights protection tend to increase over time. We present a graphical representation of coefficients of both variables from interactions with year dummies in Figure A. As seen there, the effects of extractive and non-extractive FDI on human rights continue to diverge significantly over time. This supports existing criticism that suggests that initiatives in soft and hard law against negative impacts in the extractive sectors do not go far enough in creating tangible changes on the ground (Schrempf-Stirling \& Wettstein, 2017). Since such initiatives have become stronger in recent years, it might be that improvements may take decades, and that they do not yet show in the data.

10 We thank an anonymous reviewer for pointing this out. 


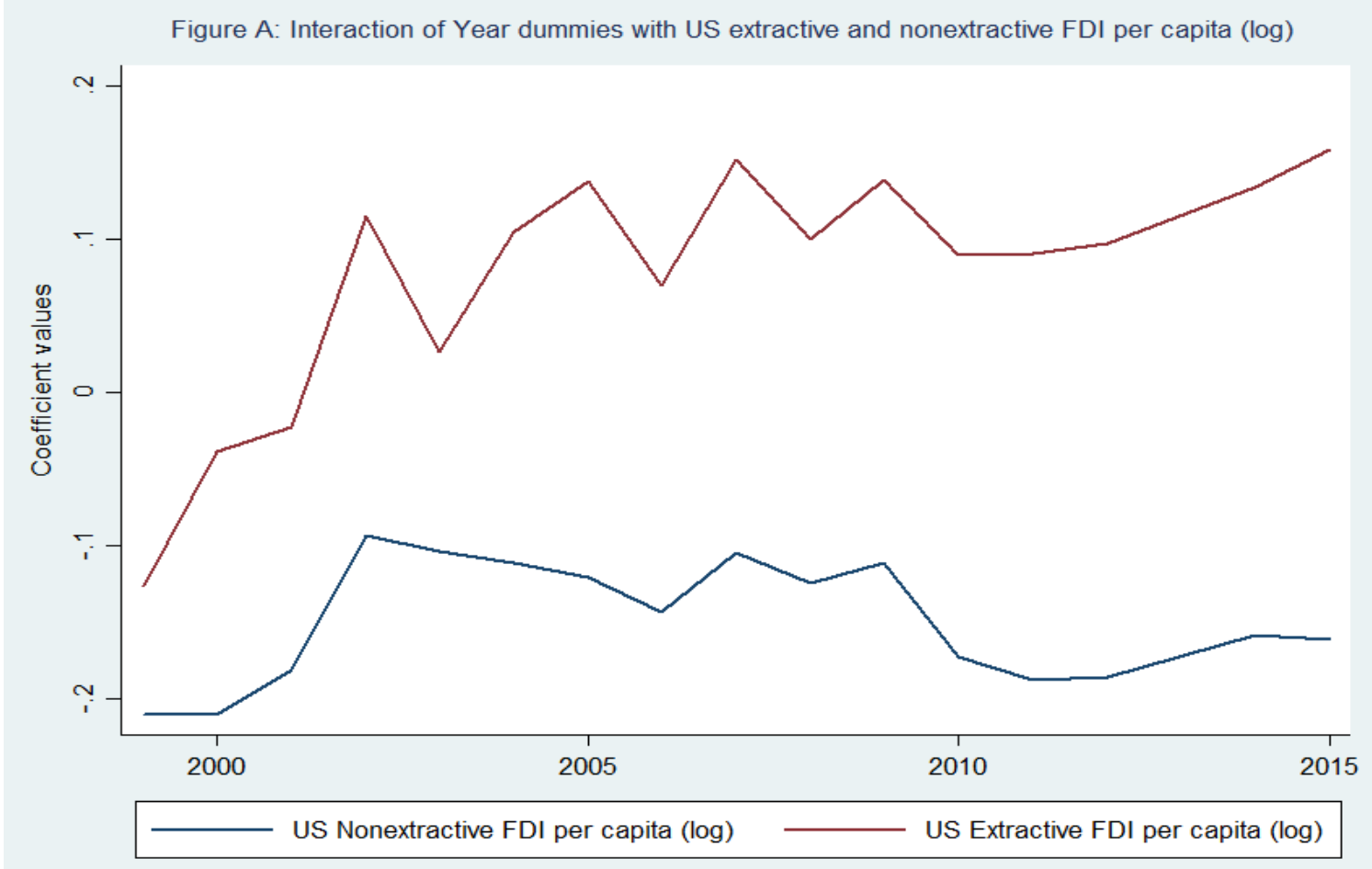

Taken together with our findings on the impact of weak institutions, future research should investigate the lack of improvement over time in more detail, and in particular, assess what is driving the worsening of extractive FDI effects versus increasingly good impact of nonextractive FDI. The fact that global consumers, such as in the garment and fashion industry, do not have ways of knowing and punishing bad behavior in the extractive sector is possibly a strong explanation.

Finally, we re-estimate all the models by dropping the variables for which we could not find any statistical significance. These include per capita income, autocracy, oil exports share dummy, and peace years. With these modifications, our results on extractive and non-extractive FDI on human rights are upheld and remain robust. These robustness results are not shown here but are reported in the supplementary file. Overall, these findings suggest that our results are robust not only to the size of the sample and alternative methods of operationalization of our main variable of interest, but they are also robust to alternative estimation techniques. 


\section{Conclusion}

Most studies on the question of FDI and human rights report positive effects, supporting the liberal contention that multinational companies bring benefits to host countries, including improvements in governance. Case-study based research, as well as studies of civil war and armed violence, often implicate multinational corporations in human rights violations and armed violence within host countries. Our study provides evidence that the impact of US FDI on human rights varies across industries. In particular, we propose that extractive firms in the oil and mining industries are bound to the location of resources, which creates a status quo bias among them when it comes to explicit, or tacit, support when dealing with repressive rulers ("locationbound effect"). We find a negative effect of extractive US FDI on human rights protection. The same is not true for non-extractive MNCs in manufacturing or services, which is connected to greater protection of human rights. We also find that strong democratic institutions can condition the negative impacts of extractive FDI on human rights ("democratic safeguard effect"), so that the effect of FDI is zero on human rights where the constraints on the executive are strong.

With these findings, we addressed an important gap in existing statistical studies on FDI and human rights. Most studies have simply used total FDI instead of disaggregating FDI. We think that sharper theory needs to focus on the heterogenous nature of FDI and its impacts on political and economic life. Recent statistical (large-N) studies on FDI suggest increasing conflict when FDI locates in mining activity, particularly in Africa (Berger et al., 2017). It stands to reason then that extractive FDI should be associated with human rights violations given that governments have a strong interest in stamping out dangerous dissent, whether companies desire such crackdowns or not. Many existing studies have stressed that "human rights behavior of multinationals may vary depending on sectoral differences" (Kim \& Trumbore, 2010, p. 732), 
proposing that "the sector invested in, determines whether foreign investment is beneficial for host countries" (Apodaca, 2002, p. 902), and that future research should examine "particular forms of FDI" (Sorens \& Ruger, 2012, p. 6). Building on a new development in the quantitative literature towards more differentiation (Blanton \& Blanton, 2009; Janz, 2018), we employ disaggregated industry-specific data to assess impacts on human rights. Our study also shows that it is important to integrate host-country conditions. Crucially, the findings suggest that qualitative case studies, alongside NGO and media reports, do not merely amount to anecdotal evidence, but they reflect larger patterns of negative impacts from extractive industries across countries and time. Future studies might probe more carefully how exactly FDI in the extractive sector balances out its obligations to multilateral initiatives relative to the economic losses from societal dissent.

The implications for policy and voluntary standards are clear: we need to see the development of stronger democratic safeguards; otherwise efforts of individual firms may not produce tangible improvements - even if some firms want to do better. Such initiatives as the Extractive Industry Transparency Initiative (EITI) have come a long way towards facilitating transparency and providing a platform for company-community conflict resolution (Lujala, Rustad, Le Billon, 2017). Finally, we find it worrying that the negative effects of non-extractive FDI on human rights protection tend to increase over time, rather than improve, as we showed in our robustness tests. This finding is preliminary, and not much time has passed since the Ruggie framework and voluntary guidelines in the extractive industry are adopted; but the finding supports criticism of soft and hard law, which suggests that these initiatives do not go far enough (Schrempf-Stirling \& Wettstein, 2017) - in particular in areas with weak democratic institutions. Global hard law initiatives might also do well to question the current norms that legalize the 
"might is right" principle when it comes to natural resources, which would give firms a massive incentive to act in ways that will constrain their support for repressive regimes (Wenar, 2016). One might also research the many ways in which local communities close to extractive activity might act as a constraint on national-level politics, and how bargaining failures between MNCs and local communities might be prevented for getting better win-win solutions.

By integrating the industry-sector level with domestic country context, we open up new avenues for statistical as well as qualitative case study work. Future quantitative research should explore further boundary conditions under which improvements of FDI on human rights can be expected, while qualitative evidence on the firm-level is equally necessary to trace under which circumstances policy changes can be more effective in protecting the rights of local communities. Why, for example, do some firms internalize a greater sense of social responsibility than others? How much leverage can companies have over governments intent on political survival, especially given the fierce competition for natural resources into the future? We encourage mixed-methods research designs for overcoming the existing disconnect between statistical analyses at the macro level and single case studies focused on the micro level. 


\section{References}

Acemoglu, D., \& Robinson, J.A. (2008). Persistence of powers, elites and institutions. American Economic Review, 98, 267-93.

Apodaca, C. (2001). Global economic patterns and personal integrity rights after the Cold War. International Studies Quarterly, 45(4), 587-602.

Apodaca, C. (2002). The Globalization of Capital in East and Southeast Asia: Measuring the Impact on Human Rights Standards. Asian Survey 24(6), 883-905.

Arellano, M. \& Bover, O. (1995). Another look at the instrumental-variable estimation of errorcomponents models. Journal of Econometrics, 68, 29-51.

Arellano, M. \& Bond, S. (1991). Some tests of specification for panel data: Monte carlo evidence and application to employment equations. Review of Economic Studies, 58(2), 277-297.

Asiedu, E. (2006). Foreign Direct Investment in Africa: The Role of Natural Resources, Market Size, Government Policy, Institutions and Political Instability. The World Economy 29(1), 63-77.

Barry, C. M., Chad, C. K., \& Flynn, M. E. (2013). Avoiding the spotlight: Human rights shaming and foreign direct investment. International Studies Quarterly, 57(3), 532-544.

Beck, N. (2001). Time-series cross-section data: What have we learned in the past few years? Annual Review of Political Science, 4(1), 271-293.

Beck, N. \& Katz, J.N. (1995). What to do (and not to do) with time-series cross-section data. American Political Science Review, 89(3), 634-647.

Berger, N., Couttenier, M., Rohner, D., \& Thoenig, M. (2017). This Mine is Mine! How Minerals Fuel Conflicts in Africa. American Economic Review 107(6), 1564-1610.

Beschorner, T. \& Hajduk, T. (2017). Responsible practices are culturally embedded: Theoretical considerations on industry-specific corporate social responsibility. Journal of Business Ethics, 143, 635-642.

Blanton, S. L., \& Blanton, R. G. (2009) A sectoral analysis of human rights and FDI: Does industry type matter? International Studies Quarterly, 53(2), 469-493.

Blanton, S. L., \& Blanton, R. G. (2006). Human rights and foreign direct investment: A twostage analysis. Business \& Society, 45(4), 464-485

Blonigen, B. A., Davies, R.B., Waddell G.R., \& Naughton, H. (2007). FDI in Space: Spatial autoregressive relationship in FDI. European Economic Review, 515, 1303-1325. 
Blundell, R. and Bond S. (1998). Initial conditions and moment restrictions in dynamic panel data models. Journal of Econometrics, 87(1), 115-143.

Böhling, K., Murguía, D. I., \& Godfrid, J. (2019). Sustainability reporting in the mining sector: exploring its symbolic nature. Business \& Society, 58(1), 191-225.

Cao, X., Greenhill, B., \& Prakash, A. (2013). Where is the tipping point? Bilateral trade and the diffusion of human rights. British Journal of Political Science, 43(1), 133-156

Chand, M., \& Fraser, S. (2006). The relationship between corporate social performance and corporate financial performance: Industry type as a boundary condition. The Business Review, 5(1), 240-245.

Christian A. (2004). Behind the mask: The real face of corporate social responsibility. London: Christian Aid.

Cingranelli, D. L. \& Richards, D. L. (1999). Measuring level, pattern and sequence of government respect for physical integrity rights. International Studies Quarterly, 43(2), 407-417.

Clapham, A. (2006). Human rights obligations of non-state actors. Oxford: Oxford University Press.

Clark, R., \& Kwon, R. (2018). Taking stock of flow: Revisiting the link between FDI and human rights. Sociology of Development, 4(4), 346-373

Cohen, S. D. (2007). Multinational corporations and foreign direct investment. Avoiding simplicity. Oxford, UK: Oxford University Press.

Dashwood, H. S. (2014). Sustainable development and industry self-regulation: Developments in the global mining sector. Business \& Society, 53(4), 551-582.

Davenport, C., \& Nordas, R. (2013). Fighting the Youth: Youth Bulges and State Repression. American Journal of Political Science, 57(4): 926-940.

Davenport, C. (2007). State repression and political order. Annual Review of Political Science. $10(1), 1-23$.

Davenport, C., \& Armstrong, D. (2004). Democracy and the Violation of Human Rights: A Statistical Analysis from 1976-1996. American Journal of Political Science, 48(3): 538554. 
Davenport, C. (1995). Multi-dimensional threat perception and state repression: An inquiry into why states apply negative sanctions. American Journal of Political Science, 39(3), 683713.

de Soysa, I., \& Vadlamannati, K.C. (2012). Do Pro-Market Economic Reforms Drive Human Rights Violations - An Empirical Assessment. Public Choice, 150, 1-25.

de Soysa, I., \& Vadlamannati, K.C. (2011) Does Being Bound Together Suffocate or Liberate? Testing the Effects of Economic, Social and Political Globalization and Human Rights, 1981-2005, Kyklos, 64(1), 20-53.

de Soysa, I., \& Binningsbø, H.M. (2009). Devil's excrement or social cement? Oil wealth and repression, 1980-2004. International Social Science Journal, 57(1), 21-32.

DiMaggio, P. J., \& Powell, W. W. (1983). The iron cage revisited: Institutional isomorphism and collective rationality in organizational fields. American sociological review, 147-160.

Dreher A., Sturm, J.E., \& Vreeland, J. (2009). Global horse trading: IMF loans for voting in the UN security council. European Economic Review, 53, 742-757.

Dunning, J. H. (1988). Explaining international production. Collins Educational.

Eweje, G. (2009). Labour relations and ethical dilemmas of extractive MNEs in Nigeria, South Africa and Zambia: 1950-2000. Journal of Business Ethics, 86(2), 207

Eweje, G. (2006a). The role of MNEs in community development initiatives in developing countries: Corporate social responsibility at work in Nigeria and South Africa. Business \& Society, 45(2), 93-129

Eweje, G. (2006b). Environmental costs and responsibilities resulting from oil exploitation in developing countries: The case of the Niger Delta of Nigeria. Journal of Business Ethics, 69(1), 27-56

Fearon, J. \& Laitin, D. (2003). Ethnicity, insurgency and civil war. American Political Science Review, 97(1), 1-16.

Fortanier, F., \& Kolk, A. (2007). On the economic dimensions of corporate social responsibility: Exploring Fortune Global 250 reports. Business \& Society, 46(4), 457-478.

Frynas, J. G. (1998). Political instability and business: focus on Shell in Nigeria. Third World Quarterly, 19(3), 457-478.

Gassebner, M., Lamla, M.J, \& Vreeland, J.R. (2009). Extreme bounds of democracy, KOF Working papers 09-224, KOF Swiss Economic Institute. 
Giuliani, E., \& Macchi, C. (2013). Multinational corporations' economic and human rights impact on developing countries: a review and research agenda. Cambridge Journal of Economics, 38(2), 479-517

Gleditsch N. P., Wallensteen, P., Eriksson, M., Sollenberg, M., and Strand, H. (2002). Armed conflict 1946-2001: A new dataset. Journal of Peace Research, 39(5), 615-637.

Globerman, S., Shapiro, D. (2003). Governance Infrastructure and Us Foreign Direct Investment. Journal of International Business Studies 34(1), 19-39.

Godfrey, P. C., Hatch, N.W., \& Hansen, J.M. (2010). Toward a general theory of CSRs: The roles of beneficence, profitability, insurance, and industry heterogeneity. Business \& Society, 49(2), 316-344.

Griffin, J. J., \& Mahon, J. F. (1997). The corporate social performance and corporate financial performance debate: Twenty-five years of incomparable research. Business \& society, 36(1), 5-31.

Hamann, R., \& Kapelus, P. (2004). Corporate social responsibility in mining in Southern Africa: Fair accountability or just greenwash? Development, 47(3), 85-92.

Hafner-Burton, Emilie M., (2005) Right or robust? The sensitive nature of repression to globalization. Journal of Peace Research, 42(6), 679-698.

Henisz, W. J. (2016). The dynamic capability of corporate diplomacy. Global Strategy Journal, 6(3), 183-196

Hertel, S. (2019). Tethered Fates: Companies, Communities, and Rights at Stake. Oxford University Press

Hilson, G. (2012). Corporate social responsibility in the extractive industries: Experiences from developing countries. Resources Policy, 37(2), 131-137.

Hymer, S. H. (1979). The multinational corporation and the law of uneven development. In Transnational Corporations and World Order: Readings in International Political Economy. George Modelski (ed.), San Francisco, CA: W. H. Freeman

Hymer, S. H. (1976). The international operations of national firms: A study of direct foreign investment, Cambridge, MIT Press

Idemudia, U. (2009). Oil extraction and poverty reduction in the Niger Delta: A critical examination of partnership initiatives. Journal of Business Ethics, 90(1), 91-116. 
Janz, N. (2018). Foreign direct investment and repression: An analysis across industry sectors. Journal of Human Rights, 17(2), 163-183.

Kim, D. H., \& Trumbore, P. F. (2010). Transnational mergers and acquisitions: The impact of FDI on human rights, 1981-2006. Journal of Peace Research, 47(6), 723-734

Kobrin, S. J. (2009). Private political authority and public responsibility: Transnational politics, transnational firms and human rights. Business Ethics Quarterly, 19(3), 349-374.

Kolk, A., Van Tulder, R., \& Westdijk, B. (2006). Poverty alleviation as business strategy? Evaluating commitments of frontrunner multinational corporations. World Development, 34(5), 789-801.

Landman, T., \& Larizza, M. (2009). Inequality and human rights: Who controls what, when, and how. International Studies Quarterly, 53(3), 715-736.

Landman, T., (2006). Holding the line: Human rights defenders in the age of terror. British Journal of Politics and International Relations, 8, 123-147

Leamer, E. E. (1983). Let's take the con out of econometrics. American Economic Review, 73(1), $31-43$.

Levine, R. \& Renelt, D. (1992). A sensitivity analysis of cross-county growth regressions. American Economic Review, 82(4), 942-63.

Lipset, S. M. (1959). Some social requisites of democracy: Economic development and political legitimacy. American political science review, 53(1), 69-105.

Lujala, P., Rustad, S. \& Le Billon, P. (2017). Has the EITI Been Successful? Reviewing Evaluations of the Extractive Industries Transparency Initiative. U4 Brief. Chr. Michelsen Institute. https://eiti.org/document/has-eiti-been-successful (last accessed: February 8, 2020).

MacDonald, G. \& McLaughlin, T. (2003) Extracting conflict. In Business and human rights: dilemmas and solutions. Rory Sullivan (ed.), Sheffield, UK: Greenleaf Publishing.

Matten, D., \& Crane, A. (2005). Corporate citizenship: Toward an extended theoretical conceptualization. Academy of Management review, 30(1), 166-179.

March, J. G., \& Olsen, J. P. (2006). Elaborating the "new institutionalism". The Oxford handbook of political institutions, 5, 3-20.

McAleer, M., Pagan, A. R. \& Volker, P. A. (1985). What will take the con out of econometrics? American Economic Review, 75, 293-307. 
McCorquodale, R. \& Fairbrother, R. (1999). Globalization and human rights. Human Rights Quarterly, 21(3), 735-766.

Meyer, W. (1996). Human rights and MNCs: Theory versus quantitative analysis. Human Rights Quarterly, 18(2), 368-397.

Meyer, K. E. (2004). Perspectives on multinational enterprises in emerging economies. Journal of international business studies, 35(4), 259-276.

Minkler, L., \& Sweeney, S. (2011). On the indivisibility and interdependence of basic rights in developing countries. Human Rights Quarterly, 351-396.

Moran, Theodore H. (2006). Harnessing Foreign Direct Investment for Development: Policies for Developed and Developing Countries (Washington, DC: Center for Global Development).

Muchlinski, P. (2001). Human rights and multinationals: Is there A problem? International Affairs, 77(1), 31-47.

Mutti, D., Yakovleva, N., Vazquez-Brust, D., \& Di Marco, M.H. (2012). Corporate social responsibility in the mining industry: Perspectives from stakeholder groups in Argentina. Resources Policy, 37(2), 212-222.

Narula, R., \& Dunning, J. (2000). Industrial development, globalization and multinational enterprises: New realities for developing countries. Oxford Development Studies, 28(2), 141-167.

Neumayer, E. (2005). Do international human rights treaties improve respect for human Rights? Journal of Conflict Resolution, 49(6), 925-953.

Newey, W. and Kenneth W. (1987). A simple positive semi-definite, heteroskedasticity and autocorrelation consistent covariance matrix. Econometrica, 55, 703-708.

Nickell, S. J. (1981). Biases in dynamic models with fixed effects. Econometrica, 49, 1417-1426.

OECD (2011), OECD Guidelines for Multinational Enterprises, OECD Publishing. 2011 Edition. Available at: http://dx.doi.org/10.1787/9789264115415-en

OECD (2013), OECD Due Diligence Guidance for Responsible Supply Chains of Minerals from Conflict-Affected and High-Risk Areas: Second Edition, OECD Publishing. Available from: http://dx.doi.org/10.1787/9789264185050-en. 
OECD (2017), OECD Due Diligence Guidance for Meaningful Stakeholder Engagement in the Extractive Sector, OECD Publishing, Paris. Available from: http://dx.doi.org/10.1787/9789264252462-en.

Poe, S. C. (2004) The decision to repress: An integrative theoretical approach to research on human rights and repression, In Sabine Carey and Steven Poe, eds. Understanding human rights violations: New systematic studies, Ashgate Publishing.

Poe, S. C., Carey, S.C., \& Vazquez, T.C. (2001). How Are These Pictures Different? A Quantitative Comparison of the US State Department and Amnesty International Human Rights Reports, 1976-1995. Human Rights Quarterly, 23, 650-77.

Poe, S. C., Neal T. \& Linda C. K. (1999). Repression of human right to personal integrity revisited: A global cross-national study covering the years 1976-1993. International Studies Quarterly, 43, 291-313.

Poe, S. C. \& Tate, N.C. (1994) Repression of human rights to personal integrity in the 1980s: A global analysis. American Political Science Review, 88(4), 853-872.

Qian, N. \& Yanagizawa, D. (2009). The Strategic Determinants of U.S. Human Rights Reporting: Evidence from the Cold War. Journal of the European Economic Association, 7, 446-457.

Rasche, A., Waddock, S., \& McIntosh, M. (2013). The United Nations global compact: Retrospect and prospect. Business \& Society, 52(1), 6-30.

Ratner, S. R. (2001). Corporations and human rights. A theory of legal responsibility. The Yale Law Journal, 111(3), 443-545.

Roodman, D. (2006). How to do xtabond2: An introduction to "difference" and "system" GMM in Stata. Centre for Global Development Working paper No. 103.

Rodrik, D. (1997). Has globalization gone too far? Washington, DC: Institute for International Economics.

Ross, M. L. (2001). Does oil hinder democracy? World Politics, 53(April), 325-361.

Ruggie, John. "Protect, respect and remedy: A framework for business and human rights." Innovations: Technology, Governance, Globalization 3.2 (2008): 189-212.

Ruggie, J. (2011). Guiding Principles on Business and Human Rights: Implementing the UN "Protect, Respect and Remedy" Framework. Report of the Special Representative of the 
Secretary General on the issue of human rights and transnational corporations and other business enterprises. Available at:

https://www.ohchr.org/documents/publications/GuidingprinciplesBusinesshr_eN.pdf

Sala-i-Martin, X. (1997). I just ran two million regressions. American Economic Review, 87(2), 178-183.

Scherer, A. G., \& Palazzo, G. (2011). The new political role of business in a globalized world: A review of a new perspective on CSR and its implications for the firm, governance, and democracy. Journal of management studies, 48(4), 899-931.

Schrempf-Stirling, J., \& Wettstein, F. (2017). Beyond guilty verdicts: human rights litigation and its impact on corporations' human rights policies. Journal of Business Ethics, 145, 545562.

Scott, R. W. (1995). Institutions and organizations: Foundations for organizational science. Sage, Thousand Oaks, California.

Smith, J., Melissa B. \& Ippolito, A. (1999). Human rights and the global economy: A response to Meyer. Human Rights Quarterly, 21(1), 207-219.

Sorens, J., \& Ruger, W. (2012). Does foreign investment really reduce repression? International Studies Quarterly, 56(2), 427-436.

Spar D. L. (1999). Foreign investment and the pursuit of human rights. Challenge, JanuaryFebruary.

Spar D. L. (1998). The spotlight and the bottom Line: How multinationals export human rights. Foreign Affairs, 77, 7-12.

Stiglitz, J. E. (2002). Globalization and its discontents, London: W.W. Norton.

Vadlamannati, K.C., Nicole J., \& Øyvind I.B. (2018). Human rights shaming and FDI: effects of the UN human rights commission and council. World Development 104 (2018): 222-237.

Vernon, R. (1971). Sovereignty at bay: The multinational spread of US enterprises, New York: Basic Books.

Vogel, D. (2010). The private regulation of global corporate conduct: Achievements and limitations. Business \& Society, 49(1), 68-87.

Vogel, D. (2005). Is there a market for virtue? The business case for corporate social responsibility. California management review, 47(4), 19-45. 
Walker, S. \& Poe, S. C. (2002). Does cultural diversity affect countries' respect for human rights? Human Rights Quarterly, 24, 237-63.

Wang, Z. (2017). Democracy, policy interdependence, and labor rights. Political Research Quarterly, 70(3), 549-563

Wenar, Leif. 2016. Blood Oil: Tyrants, Violence, and the Rules That Run the World. Oxford: Oxford University Press.

Westermann-Behaylo, M. K., Rehbein, K., \& Fort, T. (2015). Enhancing the concept of corporate diplomacy: Encompassing political corporate social responsibility, international relations, and peace through commerce. Academy of Management Perspectives, 29(4), 387-404.

Wettstein, F. (2009). Multinational corporations and global justice. Human rights obligations of a quasi-governmental institution. Stanford: Stanford University Press.

Wettstein, F. (2010). The duty to protect: Corporate complicity, political responsibility, and human rights advocacy. Journal of Business Ethics, 96(1), 33-47.

Wettstein, F., E. Giuliani, G. D. Santangelo, G. K. Stahl. (2019). International business and human rights: A research agenda. Journal of World Business 54, 54-65.

Williamson, J. (2000). What should the World Bank think about the Washington consensus? World Bank Research Observer, 15(2), 251-264.

Williamson, J. (1990). Latin American adjustment: How much has it happened? Washington, DC: Institute for International Economics. 
Table 1: Aggregated and disaggregated measures of FDI and Human Rights

\begin{tabular}{|c|c|c|c|c|c|}
\hline & $\begin{array}{c}\text { (1) } \\
\text { PTS }\end{array}$ & $\begin{array}{c}(2) \\
\text { PTS }\end{array}$ & $\begin{array}{c}(3) \\
\text { PTS }\end{array}$ & $\begin{array}{c}(4) \\
\text { PTS }\end{array}$ & $\begin{array}{c}(5) \\
\text { PTS }\end{array}$ \\
\hline US FDI percapita $(\log ) \mathrm{t}-1$ & $\begin{array}{l}-0.0373 \\
(0.0283)\end{array}$ & $\begin{array}{c}-0.0616^{* *} \\
(0.0281)\end{array}$ & & & \\
\hline US Non-extractive FDI percapita $(\log ) \mathrm{t}-1$ & & & $\begin{array}{c}-0.0907^{* * *} \\
(0.0348)\end{array}$ & $\begin{array}{c}-0.118^{* * *} \\
(0.0347)\end{array}$ & $\begin{array}{c}-0.0864^{* * *} \\
(0.0329)\end{array}$ \\
\hline US Extractive FDI percapita $(\log ) \mathrm{t}-1$ & & & $\begin{array}{c}0.0897^{* *} \\
(0.0415)\end{array}$ & $\begin{array}{l}0.101^{* *} \\
(0.0419)\end{array}$ & $\begin{array}{c}0.0789 * * \\
(0.0401)\end{array}$ \\
\hline Per capita GDP $(\log ) \mathrm{t}-1$ & & $\begin{array}{c}0.0491 \\
(0.0856)\end{array}$ & & $\begin{array}{c}0.114 \\
(0.0888)\end{array}$ & $\begin{array}{c}0.142^{*} \\
(0.0846)\end{array}$ \\
\hline Population (log) t-1 & & $\begin{array}{c}0.351^{* * *} \\
(0.134)\end{array}$ & & $\begin{array}{c}0.193 \\
(0.144)\end{array}$ & $\begin{array}{c}0.201 \\
(0.143)\end{array}$ \\
\hline Democracy dummy t-1 & & $\begin{array}{c}-0.280^{* * *} \\
(0.0555)\end{array}$ & & $\begin{array}{c}-0.323^{* * *} \\
(0.0591)\end{array}$ & $\begin{array}{c}-0.216^{* * *} \\
(0.0568)\end{array}$ \\
\hline Autocracy dummy t-1 & & $\begin{array}{l}0.0499 \\
(0.118)\end{array}$ & & $\begin{array}{c}0.167 \\
(0.126)\end{array}$ & $\begin{array}{c}0.189 \\
(0.116)\end{array}$ \\
\hline Oil exports dummy $\mathrm{t}-1$ & & $\begin{array}{c}0.0108 \\
(0.0564)\end{array}$ & & $\begin{array}{c}0.0216 \\
(0.0590)\end{array}$ & $\begin{array}{c}0.0314 \\
(0.0550)\end{array}$ \\
\hline Civil war dummy t-1 & & $\begin{array}{l}0.405^{* * *} \\
(0.0434)\end{array}$ & & $\begin{array}{l}0.408^{* * *} \\
(0.0454)\end{array}$ & $\begin{array}{l}0.177^{* * *} \\
(0.0445)\end{array}$ \\
\hline Peace Years $\mathrm{t}-1$ & & $\begin{array}{l}-0.00247 \\
(0.00221)\end{array}$ & & $\begin{array}{l}-0.00165 \\
(0.00245)\end{array}$ & $\begin{array}{c}-0.000658 \\
(0.00240)\end{array}$ \\
\hline Lagged Dependent Variable & & & & & $\begin{array}{l}0.422^{* * *} \\
(0.0226)\end{array}$ \\
\hline Constant & $\begin{array}{c}4.645^{* * *} \\
(0.114) \\
\end{array}$ & $\begin{array}{l}-2.298 \\
(2.567) \\
\end{array}$ & $\begin{array}{c}4.663^{* * *} \\
(0.115)\end{array}$ & $\begin{array}{l}0.0147 \\
(2.751) \\
\end{array}$ & $\begin{array}{l}-1.961 \\
(2.721) \\
\end{array}$ \\
\hline Extimations & GLS-FE & GLS-FE & GLS-FE & GLS-FE & GLS-FE \\
\hline Country Fixed Effects & Yes & Yes & Yes & Yes & Yes \\
\hline Year Fixed Effects & Yes & Yes & Yes & Yes & Yes \\
\hline Number of Observations & 2,080 & 1,980 & 1,888 & 1,802 & 1,652 \\
\hline Number of Countries & 157 & 150 & 156 & 150 & 149 \\
\hline
\end{tabular}

Notes: Robust standard errors in parentheses $* * * \mathrm{p}<0.01, * * \mathrm{p}<0.05, * \mathrm{p}<0.1$ 
Table 2: Aggregated and disaggregated measures of FDI and Human Rights - Ordered Logit

\begin{tabular}{|c|c|c|c|c|}
\hline & $\begin{array}{c}(1) \\
\text { PTS } \\
\end{array}$ & $\begin{array}{c}(2) \\
\text { PTS } \\
\end{array}$ & $\begin{array}{c}(3) \\
\text { PTS } \\
\end{array}$ & $\begin{array}{c}(4) \\
\text { PTS } \\
\end{array}$ \\
\hline US FDI percapita $(\log ) \mathrm{t}-1$ & $\begin{array}{c}-0.635^{* * *} \\
(0.0309)\end{array}$ & $\begin{array}{c}-0.226^{* * *} \\
(0.0503)\end{array}$ & & \\
\hline US Non-extractive FDI percapita $(\log ) \mathrm{t}-1$ & & & $\begin{array}{c}-0.744^{* * *} \\
(0.0409)\end{array}$ & $\begin{array}{c}-0.351^{* * *} \\
(0.0596)\end{array}$ \\
\hline US Extractive FDI percapita (log) t-1 & & & $\begin{array}{l}0.119 * * \\
(0.0510)\end{array}$ & $\begin{array}{c}0.127^{*} \\
(0.0758)\end{array}$ \\
\hline Per capita GDP $(\log ) \mathrm{t}-1$ & & $\begin{array}{l}-0.500^{* * *} \\
(0.0584)\end{array}$ & & $\begin{array}{l}-0.453^{* * *} \\
(0.0627)\end{array}$ \\
\hline Population $(\log ) \mathrm{t}-1$ & & $\begin{array}{l}0.521^{* * *} \\
(0.0332)\end{array}$ & & $\begin{array}{l}0.557^{* * *} \\
(0.0348)\end{array}$ \\
\hline Democracy dummy t-1 & & $\begin{array}{c}-1.095^{* * *} \\
(0.115)\end{array}$ & & $\begin{array}{c}-1.145^{* * *} \\
(0.121)\end{array}$ \\
\hline Autocracy dummy t-1 & & $\begin{array}{l}-0.0271 \\
(0.137)\end{array}$ & & $\begin{array}{c}-0.0792 \\
(0.140)\end{array}$ \\
\hline Oil exports dummy $\mathrm{t}-1$ & & $\begin{array}{c}0.699 * * * \\
(0.109)\end{array}$ & & $\begin{array}{c}0.505^{* * *} \\
(0.114)\end{array}$ \\
\hline Civil war dummy t-1 & & $\begin{array}{c}2.088^{* * *} \\
(0.169)\end{array}$ & & $\begin{array}{c}2.134^{* * *} \\
(0.177)\end{array}$ \\
\hline Peace Years t-1 & & $\begin{array}{c}-0.0100^{* * *} \\
(0.00263)\end{array}$ & & $\begin{array}{c}-0.00684^{* *} \\
(0.00267)\end{array}$ \\
\hline Extimations & Ologit & Ologit & Ologit & Ologit \\
\hline Country Fixed Effects & No & No & No & No \\
\hline Year Fixed Effects & Yes & Yes & Yes & Yes \\
\hline Number of Observations & 2,080 & 1,980 & 1,888 & 1,802 \\
\hline Number of Countries & 157 & 150 & 156 & 150 \\
\hline
\end{tabular}

Notes: Robust standard errors in parentheses $* * * \mathrm{p}<0.01, * * \mathrm{p}<0.05, * \mathrm{p}<0.1$ 
Table 3: Aggregated and disaggregated measures of FDI and Human Rights - GMM

\begin{tabular}{|c|c|c|c|c|}
\hline & $\begin{array}{c}(\mathbf{1}) \\
\text { PTS } \\
\end{array}$ & $\begin{array}{c}(2) \\
\text { PTS } \\
\end{array}$ & $\begin{array}{c}(3) \\
\text { PTS } \\
\end{array}$ & $\begin{array}{c}(4) \\
\text { PTS } \\
\end{array}$ \\
\hline \multirow[t]{2}{*}{ US FDI percapita $(\log ) \mathrm{t}-1$} & $-0.0775^{* * *}$ & $-0.0397^{*}$ & & \\
\hline & $(0.0175)$ & $(0.0228)$ & & \\
\hline \multirow[t]{2}{*}{ US Non-extractive FDI percapita $(\log ) \mathrm{t}-1$} & & & $-0.0809 * * *$ & $-0.0635^{* * *}$ \\
\hline & & & $(0.0136)$ & $(0.0148)$ \\
\hline \multirow[t]{2}{*}{ US Extractive FDI percapita $(\log ) \mathrm{t}-1$} & & & $0.0595^{* * *}$ & $0.0833^{* * *}$ \\
\hline & & & $(0.0183)$ & $(0.0188)$ \\
\hline \multirow[t]{2}{*}{ Per capita GDP $(\log ) \mathrm{t}-1$} & & $-0.0777^{* * *}$ & & $-0.0537^{* * *}$ \\
\hline & & $(0.0221)$ & & $(0.0182)$ \\
\hline \multirow[t]{2}{*}{ Population (log) t-1 } & & $0.0991^{* * *}$ & & $0.0977^{* * *}$ \\
\hline & & $(0.0178)$ & & $(0.0126)$ \\
\hline \multirow[t]{2}{*}{ Democracy dummy t-1 } & & $-0.199 * * *$ & & $-0.150^{* * *}$ \\
\hline & & $(0.0421)$ & & $(0.0311)$ \\
\hline \multirow[t]{2}{*}{ Autocracy dummy t-1 } & & 0.0198 & & $0.0592^{*}$ \\
\hline & & $(0.0358)$ & & $(0.0341)$ \\
\hline \multirow[t]{2}{*}{ Oil exports dummy t-1 } & & $0.111^{* * *}$ & & 0.0325 \\
\hline & & $(0.0311)$ & & $(0.0240)$ \\
\hline \multirow[t]{2}{*}{ Civil war dummy t-1 } & & $0.283^{* * *}$ & & $0.174^{* * *}$ \\
\hline & & $(0.0762)$ & & $(0.0496)$ \\
\hline \multirow[t]{2}{*}{ Peace Years t-1 } & & -0.00110 & & $-0.00146^{* *}$ \\
\hline & & $(0.000949)$ & & $(0.000702)$ \\
\hline \multirow[t]{2}{*}{ Lagged Dependent Variable } & $0.684^{* * *}$ & $0.525^{* * *}$ & $0.767^{* * *}$ & $0.626^{* * *}$ \\
\hline & $(0.0589)$ & $(0.0779)$ & $(0.0249)$ & $(0.0456)$ \\
\hline Extimations & SGMM & SGMM & SGMM & SGMM \\
\hline Country Fixed Effects & No & No & No & No \\
\hline Year Fixed Effects & Yes & Yes & Yes & Yes \\
\hline Arellano-Bond test for $\mathrm{AR}(1) p$-value & 0.000 & 0.000 & 0.000 & 0.000 \\
\hline Arellano-Bond test for AR(2) $p$-value & 0.016 & 0.088 & 0.128 & 0.137 \\
\hline Hansen J-statistic [ $p$-value] & 0.223 & 0.143 & 0.141 & 0.182 \\
\hline Number of Instruments & 57 & 64 & 78 & 85 \\
\hline Number of Observations & 1,888 & 1,801 & 1,727 & 1,652 \\
\hline Number of Countries & 156 & 149 & 155 & 149 \\
\hline
\end{tabular}

Notes: Robust standard errors in parentheses $* * * \mathrm{p}<0.01, * * \mathrm{p}<0.05, * \mathrm{p}<0.1$ 
Table 4: Extractive FDI, Institutions and Human Rights - Interaction effects

\begin{tabular}{|c|c|c|c|}
\hline & $\begin{array}{c}\text { (1) } \\
\text { PTS }\end{array}$ & $\begin{array}{c}(2) \\
\text { PTS }\end{array}$ & $\begin{array}{c}(3) \\
\text { PTS }\end{array}$ \\
\hline \multirow[t]{2}{*}{ US Extractive FDI percapita (log) $\mathrm{t}-1 \mathbf{X}$ Polity index $\mathrm{t}-1$} & -0.00460 & -0.00616 & -0.00471 \\
\hline & $(0.00544)$ & $(0.00527)$ & $(0.00507)$ \\
\hline \multirow[t]{2}{*}{ Polity index $\mathrm{t}-1$} & $-0.0387^{* * *}$ & $-0.0378^{* * *}$ & $-0.0264^{* * *}$ \\
\hline & $(0.00597)$ & $(0.00586)$ & $(0.00566)$ \\
\hline \multirow[t]{2}{*}{ US Extractive FDI percapita $(\log ) \mathrm{t}-1$} & $0.151^{* * *}$ & $0.119^{* * *}$ & $0.0914^{* *}$ \\
\hline & $(0.0454)$ & $(0.0443)$ & $(0.0418)$ \\
\hline \multirow[t]{2}{*}{ US Non-extractive FDI percapita $(\log ) \mathrm{t}-1$} & $-0.119^{* * *}$ & $-0.104^{* * *}$ & $-0.0773^{* *}$ \\
\hline & $(0.0353)$ & $(0.0345)$ & $(0.0327)$ \\
\hline \multirow[t]{2}{*}{ Per capita GDP $(\log ) \mathrm{t}-1$} & & 0.0584 & 0.0989 \\
\hline & & $(0.0883)$ & $(0.0846)$ \\
\hline \multirow[t]{2}{*}{ Population $(\log ) \mathrm{t}-1$} & & 0.216 & 0.209 \\
\hline & & $(0.144)$ & $(0.144)$ \\
\hline \multirow[t]{2}{*}{ Oil exports dummy $\mathrm{t}-1$} & & 0.0329 & 0.0376 \\
\hline & & $(0.0588)$ & $(0.0549)$ \\
\hline \multirow[t]{2}{*}{ Civil war dummy t-1 } & & $0.406^{* * *}$ & $0.177^{* * *}$ \\
\hline & & $(0.0452)$ & $(0.0444)$ \\
\hline \multirow[t]{2}{*}{ Peace Years t-1 } & & -0.00180 & -0.000915 \\
\hline & & $(0.00244)$ & $(0.00239)$ \\
\hline \multirow[t]{2}{*}{ Lagged Dependent Variable } & & & $0.414^{* * *}$ \\
\hline & & & $(0.0227)$ \\
\hline \multirow[t]{2}{*}{ Constant } & $4.636^{* * *}$ & -0.0501 & -1.816 \\
\hline & $(0.218)$ & $(2.748)$ & $(2.723)$ \\
\hline Extimations & GLS-FE & GLS-FE & GLS-FE \\
\hline Country Fixed Effects & Yes & Yes & Yes \\
\hline Year Fixed Effects & Yes & Yes & Yes \\
\hline Number of Observations & 1,818 & 1,802 & 1,652 \\
\hline Number of Countries & 153 & 150 & 149 \\
\hline
\end{tabular}

Notes: Robust standard errors in parentheses $* * * \mathrm{p}<0.01, * * \mathrm{p}<0.05, * \mathrm{p}<0.1$ 
Figure 1: Marginal Effects corresponding to Table 2

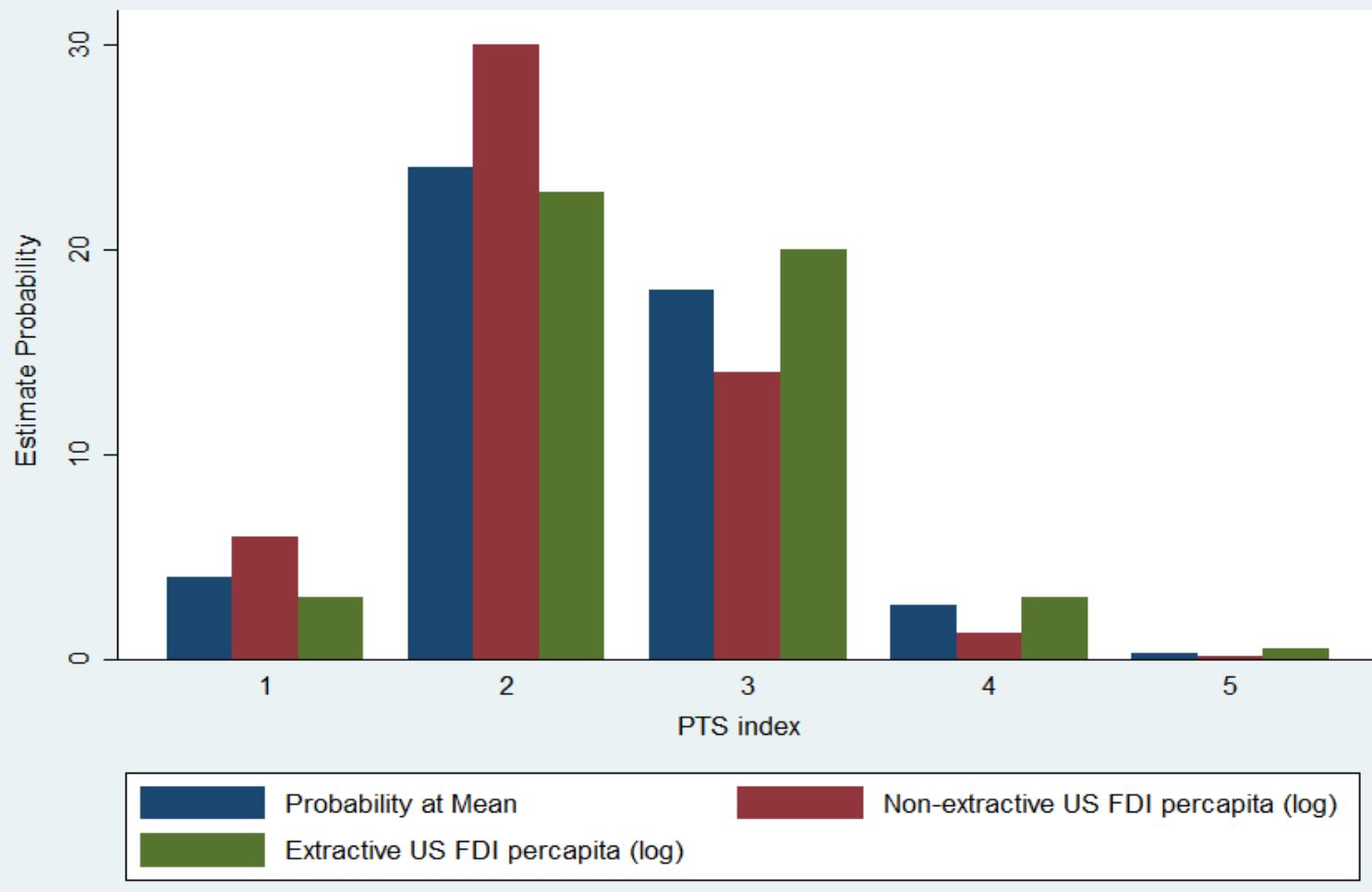

Figure 2: Extractive US FDI, Institutions \& Marginal Effect on Human Rights violations (PTS index)
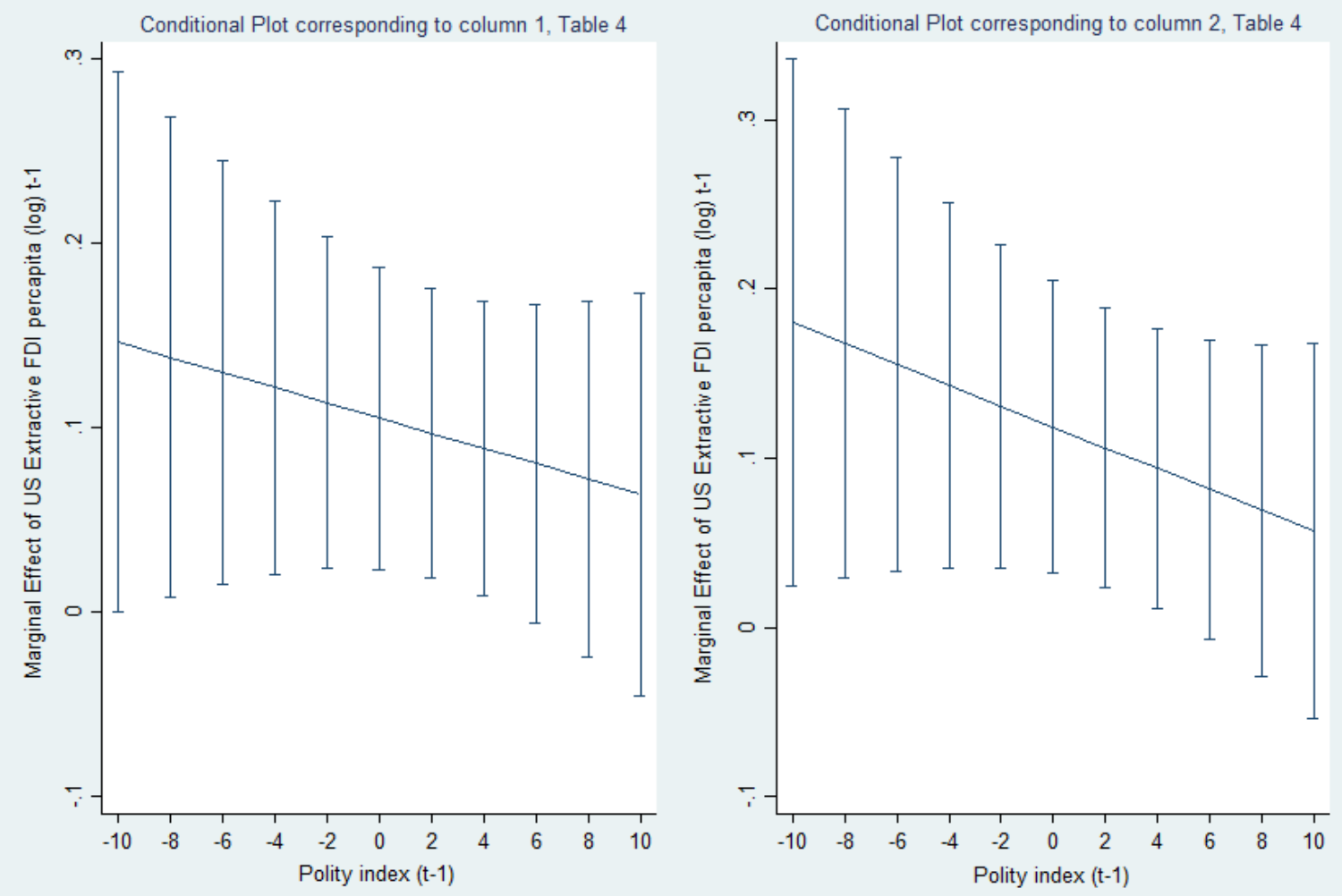


\section{Appendix}

\section{Appendix 1}

Cases registered against US firms for alleged Human rights violations under the Alien Tort Claims Act

\begin{tabular}{|c|c|c|c|}
\hline Year & $\begin{array}{l}\text { US Company facing } \\
\text { allegations }\end{array}$ & Complain party & Allegations \\
\hline 1993 & Texaco (Chevron) & $\begin{array}{l}\text { Cristóbal Bonifaz } \\
\text { and fellow lawyers }\end{array}$ & $\begin{array}{l}\text { Allegations of polluting rain forests and rivers in their countries, } \\
\text { causing environmental damage and personal injuries. }\end{array}$ \\
\hline 1999 & Chevron oil & group of Nigerians & $\begin{array}{l}\text { Allegations of human rights violations, including torture and } \\
\text { execution by Nigerian paramilitary in concert with Chevron to } \\
\text { suppress the protests against environmental practices in Niger Delta. }\end{array}$ \\
\hline 2001 & Del Monte Inc. & trade union leaders & $\begin{array}{l}\text { Allegations of torture and unlawful detention related to the union's } \\
\text { efforts to organize. }\end{array}$ \\
\hline 2001 & $\begin{array}{l}\text { Drummond coal } \\
\text { company }\end{array}$ & victims & $\begin{array}{l}\text { Allegations of murdering three union leaders at one of its mines in } \\
\text { Colombia }\end{array}$ \\
\hline 2001 & Wal-Mart & $\begin{array}{l}\text { Six female } \\
\text { employees }\end{array}$ & Allegations of discrimination in salary, bonuses and training. \\
\hline 2001 & Coca-Cola & $\begin{array}{l}\text { Colombian trade } \\
\text { union }\end{array}$ & $\begin{array}{l}\text { Allegations of assisting the paramilitary in murdering several union } \\
\text { members }\end{array}$ \\
\hline 2001 & $\begin{array}{l}\text { Exxon Mobil } \\
\text { Corporation }\end{array}$ & victims & $\begin{array}{l}\text { Allegations of hiring military to protect the oil basins leading to } \\
\text { perpetrating human rights abuses against villagers. }\end{array}$ \\
\hline 2001 & Dyn Corp. & victims & $\begin{array}{l}\text { Allegations of crimes against humanity and wrongful death on behalf } \\
\text { of Ecuadorian subsistence farmers with no connection to the drug } \\
\text { trade whose crops are being subjected to sustained, deadly aerial } \\
\text { assaults financed by the US government through DynCorp. }\end{array}$ \\
\hline 2003 & $\begin{array}{l}\text { Occidental Petroleum } \\
\text { and Airscan, Inc. }\end{array}$ & $\begin{array}{l}\text { Center for Human } \\
\text { Rights in US }\end{array}$ & $\begin{array}{l}\text { Allegations of murder of innocent civilians in the hamlet of Santo } \\
\text { Domingo, Colombia in } 1998 .\end{array}$ \\
\hline 2003 & Talisman Energy Inc. & $\begin{array}{l}\text { Presbyterian } \\
\text { Church of Sudan }\end{array}$ & $\begin{array}{l}\text { An allegation of being complicit in the Sudanese military's genocidal } \\
\text { assault, forced displacement and enslavement of non-Muslim African } \\
\text { Sudanese from } 1997 \text { to } 2003 \text {. }\end{array}$ \\
\hline 2004 & DaimlerChrysler & victims' relatives & $\begin{array}{l}\text { Allegations of disappearances and tortures of workers and union } \\
\text { leaders during Argentina's civil war }\end{array}$ \\
\hline
\end{tabular}




\begin{tabular}{|l|l|l|l|}
\hline 2004 & Unocal & $\begin{array}{l}\text { 15 villagers from } \\
\text { Myanmar }\end{array}$ & $\begin{array}{l}\text { Allegations of human right abuses during the building of a gas } \\
\text { pipeline in Myanmar }\end{array}$ \\
\hline 2005 & $\begin{array}{l}\text { Unknown list of US } \\
\text { firms }\end{array}$ & $\begin{array}{l}\text { The Khulumani } \\
\text { Support Group }\end{array}$ & $\begin{array}{l}\text { Allegations of supporting the atrocities committed by the government } \\
\text { during apartheid }\end{array}$ \\
\hline 2005 & Dow Chemical & $\begin{array}{l}\text { Victims' of Bhopal } \\
\text { Gas tragedy, India }\end{array}$ & $\begin{array}{l}\text { Allegations of flouting environmental standards leading to one of the } \\
\text { world's biggest industrial disasters. }\end{array}$ \\
\hline 2005 & $\begin{array}{l}\text { Firestone } \\
\text { (Bridgestone Corp.) }\end{array}$ & victims & $\begin{array}{l}\text { Allegations of poor working conditions at the rubber plantation and } \\
\text { amount to forced labour in Liberia. }\end{array}$ \\
\hline 2006 & Occidental Petroleum & victims & $\begin{array}{l}\text { Allegations of violating Fair Labour Standards Act and misleading } \\
\text { advertising, by labeling goods as 'sweatshop free.' }\end{array}$ \\
\hline 2009 & Shell's oil & $\begin{array}{l}\text { Allegations of using military and paramilitary death squads to guard } \\
\text { pipeline in Ecuador, resulting in against the local population. }\end{array}$ \\
\hline
\end{tabular}

Notes: The list is obviously not exhaustive due to limited availability of information. Sourced from: Alien Tort

Claims Act, retrieved from: http://www.globalpolicy.org/international-justice/alien-tort-claims-act-6-30.html 


\section{Appendix 2: List of countries under study}

\begin{tabular}{|c|c|c|c|c|}
\hline Afghanistan & China & Guyana & Mauritius & Singapore \\
\hline Albania & Colombia & Haiti & Mexico & Slovak Republic \\
\hline Algeria & Comoros & Honduras & Moldova & Slovenia \\
\hline Angola & Congo, Dem. Rep. & Hungary & Mongolia & Solomon Islands \\
\hline Antigua and Barbuda & Congo, Rep. & India & Morocco & South Africa \\
\hline Argentina & Costa Rica & Indonesia & Mozambique & Spain \\
\hline Armenia & Cote d'Ivoire & Iran, Islamic Rep. & Myanmar & Sri Lanka \\
\hline Australia & Croatia & Iraq & Namibia & Sudan \\
\hline Austria & Cuba & Ireland & Nepal & Suriname \\
\hline Azerbaijan & Cyprus & Israel & Netherlands & Swaziland \\
\hline Bahamas, The & Czech Republic & Italy & New Zealand & Sweden \\
\hline Bahrain & Denmark & Jamaica & Nicaragua & Switzerland \\
\hline Bangladesh & Djibouti & Japan & Niger & Syrian Arab Republic \\
\hline Barbados & Dominican Republic & Jordan & Nigeria & Tajikistan \\
\hline Belarus & Ecuador & Kazakhstan & Norway & Tanzania \\
\hline Belgium & Egypt, Arab Rep. & Kenya & Oman & Thailand \\
\hline Belize & El Salvador & Korea, Dem. People's Rep. & Pakistan & Timor-Leste \\
\hline Benin & Equatorial Guinea & Korea, Rep. & Panama & Togo \\
\hline Bhutan & Eritrea & Kuwait & Papua New Guinea & Trinidad and Tobago \\
\hline Bolivia & Estonia & Kyrgyz Republic & Paraguay & Tunisia \\
\hline Bosnia and Herzegovina & Ethiopia & Lao PDR & Peru & Turkey \\
\hline Botswana & Fiji & Latvia & Philippines & Turkmenistan \\
\hline Brazil & Finland & Lebanon & Poland & Uganda \\
\hline Brunei Darussalam & France & Lesotho & Portugal & Ukraine \\
\hline Bulgaria & Gabon & Liberia & Qatar & United Arab Emirates \\
\hline Burkina Faso & Gambia, The & Libya & Romania & United Kingdom \\
\hline Burundi & Georgia & Lithuania & Russian Federation & United States \\
\hline Cabo Verde & Germany & Macedonia, FYR & Rwanda & Uruguay \\
\hline Cambodia & Ghana & Madagascar & Sao Tome and Principe & Uzbekistan \\
\hline Cameroon & Greece & Malawi & Saudi Arabia & Venezuela, RB \\
\hline Canada & Grenada & Malaysia & Senegal & Vietnam \\
\hline Central African Republic & Guatemala & Maldives & Serbia & Yemen, Rep. \\
\hline Chad & Guinea & Mali & Seychelles & Zambia \\
\hline Chile & Guinea-Bissau & Mauritania & Sierra Leone & Zimbabwe \\
\hline
\end{tabular}


Appendix 3: Descriptive Statistics

\begin{tabular}{lccccc}
\hline \multicolumn{1}{c}{ Variables } & Mean & Standard Deviation & Minimum & Maximum & Observations \\
\hline PTS index & 2.686 & 1.084 & 1.000 & 5.000 & 3498 \\
US FDI percapita & 12.094 & 55.733 & -4.335 & 890.653 & 3674 \\
US FDI percapita (log) & 1.119 & 1.565 & -2.173 & 7.485 & 3674 \\
US Non-extractive FDI percapita & 10.956 & 53.566 & -4.361 & 889.222 & 3492 \\
US Non-extractive FDI percapita (log) & 1.008 & 1.524 & -2.179 & 7.483 & 3492 \\
US Extractive FDI percapita & 0.658 & 3.059 & -2.460 & 46.218 & 3642 \\
US Extractive FDI percapita (log) & 0.249 & 0.674 & -1.632 & 4.527 & 3642 \\
Per capita GDP (log) & 8.237 & 1.530 & 4.752 & 11.425 & 4240 \\
Population (log) & 15.889 & 1.741 & 11.108 & 21.039 & 4413 \\
Democracy dummy & 0.441 & 0.497 & 0.000 & 1.000 & 4066 \\
Autocracy dummy & 0.151 & 0.358 & 0.000 & 1.000 & 4066 \\
Oil exports dummy & 0.259 & 0.438 & 0.000 & 1.000 & 4405 \\
Civil war dummy & 0.173 & 0.378 & 0.000 & 1.000 & 4130 \\
Peace years & 23.094 & 21.309 & 0.000 & 69.000 & 4130 \\
\hline
\end{tabular}

Appendix 4: Data sources and definitions

\begin{tabular}{|c|c|}
\hline & Data definition and sources \\
\hline PTS index & $\begin{array}{l}\text { ded on } 1-5 \text { scale wherein } 1 \text { means proper rule of law, no illegal detentions, } \\
\text { d torture is exceptional and extra judiciary murders are extremely rare } \\
\text { urced from Gibney et al. (2012) }\end{array}$ \\
\hline US FDI measures & $\begin{array}{l}\text { Extractive, Non-extractive and total US FDI per capita (log) sourced from the } \\
\text { Bureau of Economic Analysis (BEA) statistics 2019, Washington D.C. }\end{array}$ \\
\hline J & $\begin{array}{l}\text { GDP per head in } 2000 \text { US\$ constant prices sourced from the World } \\
\text { Development Indicators } 2018 \text {, World Bank. }\end{array}$ \\
\hline $\mathrm{cy}$ & $\begin{array}{l}\text { Based on Polity IV index }(-10 \text { to }+10) \text { takes the value } 1 \text { if the Polity IV index is } \\
+6 \text { and above and } 0 \text { otherwise. }\end{array}$ \\
\hline & $\begin{array}{l}\mathrm{x}(-10 \text { to }+10) \text { takes the value } 1 \text { if the Polity IV index is } \\
\text { wise. }\end{array}$ \\
\hline & $\begin{array}{l}\text { Total population count (logged) sourced from the World Development } \\
\text { Indicators 2018, World Bank. }\end{array}$ \\
\hline rts c & $\begin{array}{l}\text { value } 1 \text { if a country } i \text { in year } t \text { natural resources exports are more } \\
\text { of the country's total exports sourced from World Bank dataset. }\end{array}$ \\
\hline & $\begin{array}{l}\text { Dummy coded } 1 \text { for each year a country has at least one active conflict } \\
\text { obtained from the Uppsala Conflict Data Program, } 2016\end{array}$ \\
\hline & $\begin{array}{l}\text { Count of number of peace years sourced from the Uppsala Conflict Data } \\
\text { Program, } 2016\end{array}$ \\
\hline
\end{tabular}

